Vet. Res. (2008) 39:54

www.vetres.org

DOI: $10.1051 /$ vetres:2008030

C INRA, EDP Sciences, 2008

Review article

\title{
Membrane markers of the immune cells in swine: an update
}

\author{
Laurence Piriou-GuZYLACK ${ }^{1}$, Henri SALMON ${ }^{2 *}$ \\ ${ }^{1}$ Institute of Virology and Immunoprophylaxis, CH-3147 Mittelhäusern, Switzerland \\ ${ }^{2}$ Institut National de la Recherche Agronomique, INRA, UR1282, Infectiologie Animale et Santé Publique \\ (IASP), Equipe Lymphocyte et Immunité des Muqueuses, Nouzilly, F-37380, France
}

(Received 6 February 2008; accepted 16 July 2008)

\begin{abstract}
Besides their breeding value, swine are increasingly used as biomedical models. As reported in three international swine clusters of differentiation (CD) workshops and in the animal homologue section of the last workshop for the determination of human leukocyte differentiation antigens (HLDA 8), characterisation of leukocyte surface antigens by monoclonal antibodies and other molecular studies have determined the cell lineages and blood leukocyte subsets implicated in the immune response, including cell adhesion molecules involved in cell trafficking. This review focusses on the current state of knowledge of porcine leukocyte differentiation and major histocompatibility complex (SLA) molecules. Examples of porcine particularities such as the double-positive $\mathrm{T}$ lymphocytes with the phenotype $\mathrm{CD} 4{ }^{+} \mathrm{CD} 8^{\text {low }}$ and $\mathrm{CD} 4^{-} \mathrm{CD} 8^{\text {low }} \alpha \beta \mathrm{T}$ cell subsets and the persistence of SLA class II after T-lymphocyte activation are illustrated, as well as the shared characteristics of the Artiodactyla group, such as the high proportion of $\gamma \delta \mathrm{TcR}$ (T cell receptor) T cells in blood and other lymphoid tissues. Furthermore, discrepancies between swine and humans, such as CD16 expression on dendritic cells and CD11b (wCD11R1) tissue distribution are outlined. The rapidly growing information should facilitate manipulation of the swine immune system towards improving disease control, and open new avenues for biomedical research using the pig as a model.
\end{abstract}

cluster of differentiation (CD) / monoclonal antibody / immune system / histocompatibility system / pig

\section{Table of contents}

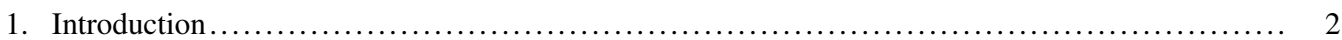

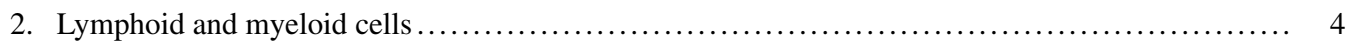

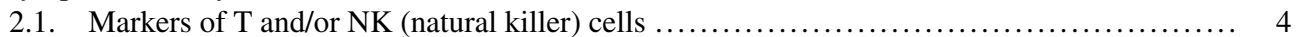

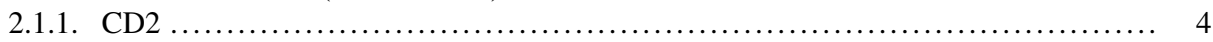

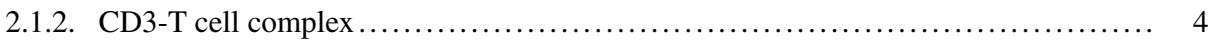

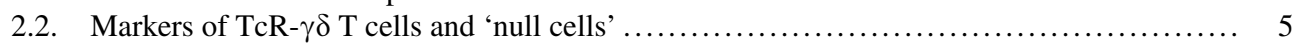

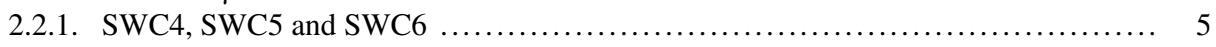

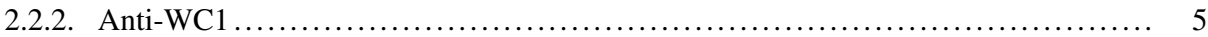

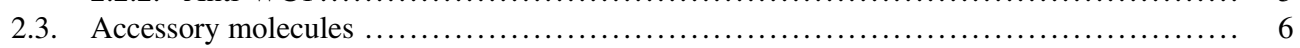

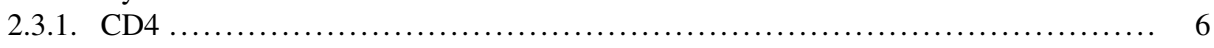

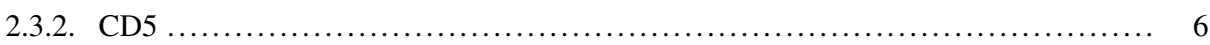

* Corresponding author: salmon@ tours.inra.fr

Article available at http://www.vetres.org or http://dx.doi.org/10.1051/vetres:2008030 


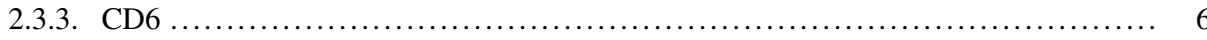

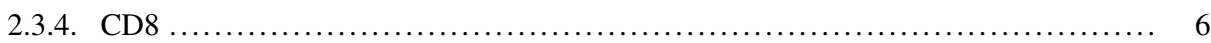

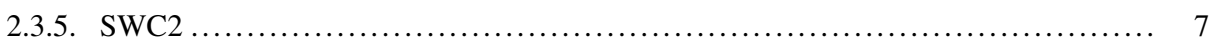

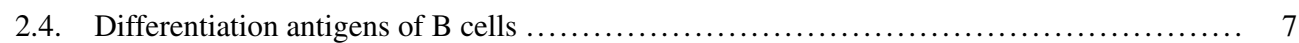

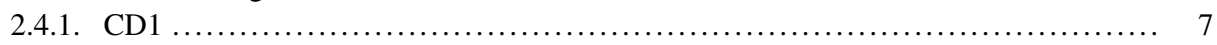

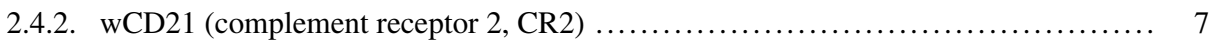

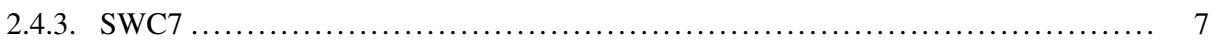

2.4.4. Cross-reacting anti-human (anti-h) B cell mAb............................ 7

2.5. Differentiation antigens of monocytes, macrophages and dendritic cells ............... 8

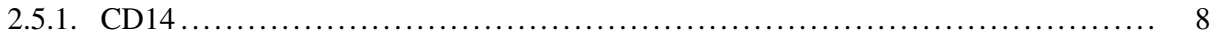

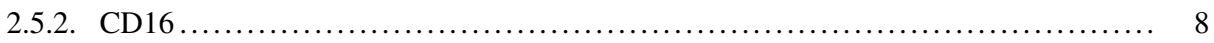

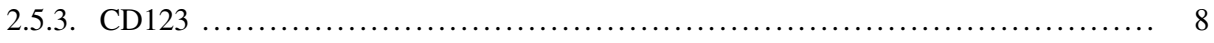

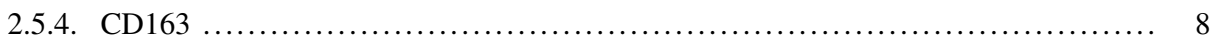

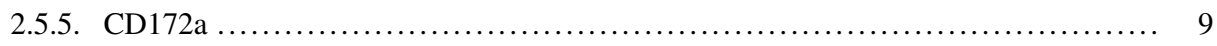

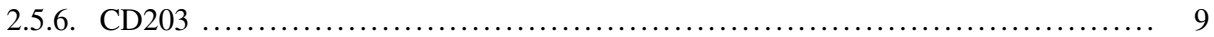

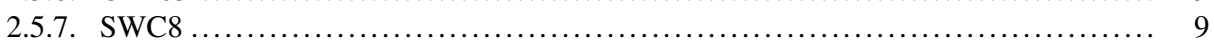

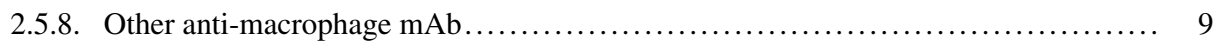

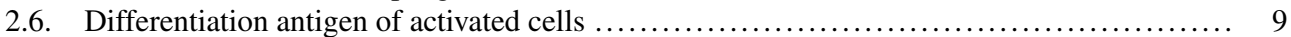

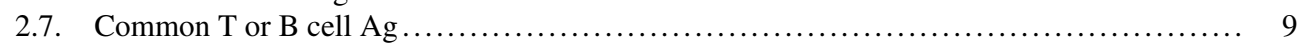

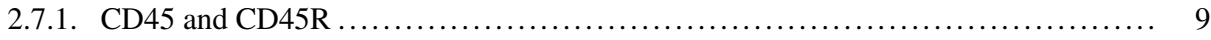

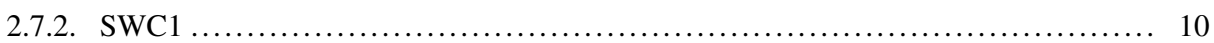

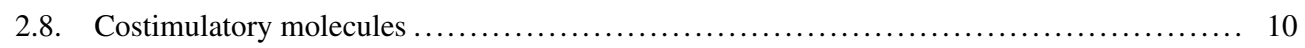

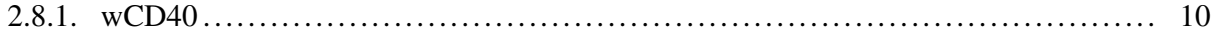

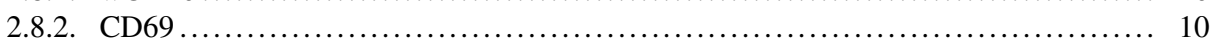

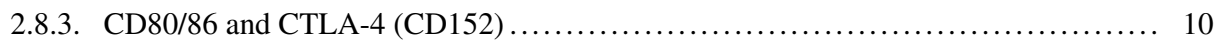

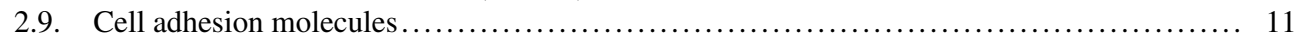

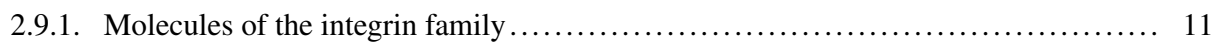

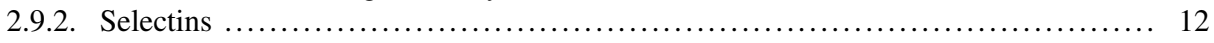

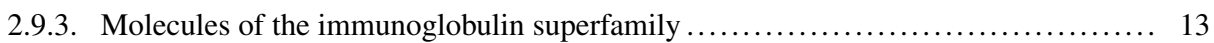

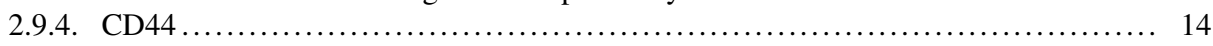

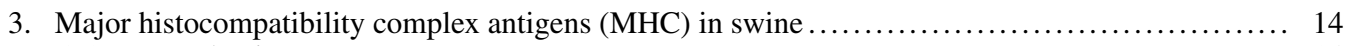

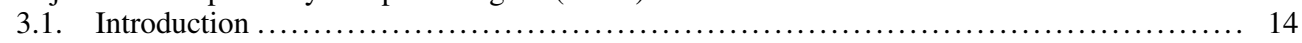

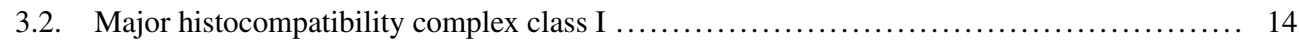

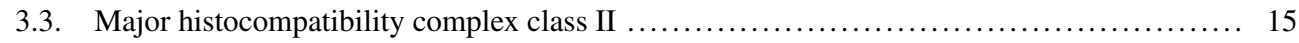

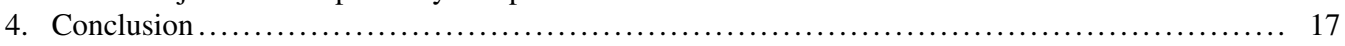

\section{INTRODUCTION}

Specific identification of the various subpopulations of leukocytes enables improved investigations of the immune response to various porcine infections such as Actinobacillus pleuropneumoniae, African swine fever virus, classical swine fever virus, porcine reproductive and respiratory syndrome virus (PRRSV) and Aujeszky disease virus $[6,41,76,110$, $116,127,137,213]$. An understanding of these interactions is essential for the development of new generations of vaccines. This field has also been promoted by the potential values of the pig as a model for biomedical studies due to anatomical and physiological similarities with humans and as an important source of tissues or organs for xenotransplantation $[106,178]$. This has led to an increase in the number of scientists interested in this species, well beyond the restricted numbers focussing on the pig due to its economical importance. The unique aspect of $\mathrm{T}$ cell biology in the pig makes this species particularly suitable for 
studying the generation of $\mathrm{T}$ cell subset diversity and tissue distribution. Pigs have been used, since 1966, to study the ontogenesis of the immune response $[41,156,201,227]$ within a foetal development not influenced by maternal antibodies and antigens. These studies concluded that piglets are immunocompetent at birth [22], albeit with a largely 'immature' immune system that has not been previously in contact with antigens, resulting in a primary immune response, a less developed mucosal immune response and lower repertoire diversity than in adults [182]. Piglets also constitute a unique material for studying the development of the postnatal immune response [120] without any other antigenic stimulus, since they can be reared in germ-free $[179,222]$ and antigen-free environments [108, 129]. However, certain characteristics of the porcine lymphoid system may affect the immune system, and thus require the development of appropriate cellular and molecular reagents and tools [184].

The recent development of monoclonal antibodies (mAb) directed against membrane molecules of porcine leukocytes has made it possible to improve the characterisation of the phenotype and functions of various porcine leukocyte populations. Various international workshops have been organised for the identification of porcine cell surface proteins, classified as clusters of differentiation (CD) using $\mathrm{mAb}$. The first international workshop on differentiation markers was held in 1992 in Budapest (Hungary), the second in 1995 in Davis, CA (USA) and the third in 1998 in Ludhiana (India) [89, 118, 122, 157, 174]. The different workshops made it possible to produce an inventory of the various antibodies and molecular reagents available for the same reactivity cluster or differentiation group, specifically in pigs (Table A, available online only at www.vetres.org) $)^{1}$. Cross-reactivity studies have been made with well defined

\footnotetext{
${ }^{1}$ Informative websites on swine immune markers: Porcine Immunology and Nutrition (PIN) database [online] http://www.ars.usda.gov/Services/ docs.htm?docid=6065 [consulted 08/04/2008]; Veterinary Immune Reagent Network [online]
}

$\mathrm{mAb}$ directed against human leukocyte differentiation antigens showing speciesoverlapping reactivities $[33,171]$. In these studies, care was taken to include a broad panel of lymphoid cells and specialised cell populations in order to ensure that the $\mathrm{mAb}$ were clustered appropriately. Thus, in addition to analyses of peripheral blood mononuclear cells (PBMC) and lymphoid tissues, analyses of representative cell subsets and cell lines, such as B-cell lines, [98, 99], alveolar macrophages, $\gamma \delta$ TCR-expressing cell lines foetal liver cells, SLA I-transfected mouse fibroblasts and T-cell lines have been carried out [164].

The assignment of $\mathrm{mAb}$ reactivity to $\mathrm{CD}$ has been standardised, using the following criteria: (i) the binding to the cluster of two or more $\mathrm{mAb}$ resulted in a pattern of reactivity that was typical of the same CD on human cells; (ii) the molecular weight (MW) of the antigen was similar to that of the human antigen; (iii) finally, the reactivity with the gene product or functional studies of the identified molecule were required to obtain official swine CD number assignment [122]. Antigens recognised by $\mathrm{mAb}$ without fulfilling all of these criteria were labelled with the prefix ' $w$ ' (workshop, see Table A). If the pattern of cell binding reactivity for the cluster of pig mAb differed from that of any known human $\mathrm{CD}$ antigen, then the cluster of $\mathrm{mAb}$ was assigned a swine workshop cluster number (SWC number, see Table A). Where detailed epitope analyses were performed, identified epitopes were denoted by a letter following the $\mathrm{CD}$ or SWC number (e.g. CD172a or CD8a, b, c, Table A) $[122,160,174,251]$. The lack of a letter means that no epitope was

http://www.umass.edu/vetimm/swine/index.html [consulted 08/04/2008]; and Porcine Immunology Resources [online] http://eis.bris.ac.uk/ lvkh/ donors.htm [consulted 08/04/2008]; commercial websites such as RDI [online] http://www. researchd.com/pigcdabs/pigcdabs.htm [consulted 08/04/2008]; and eBioscience [online] http://www. ebioscience.com/ebioscience/whatsnew/humancdchart.htm [consulted 08/04/2008]. 
assigned for that $\mathrm{mAb}$. It is important to note that cross reactivity with $\mathrm{CD}$ from other species does not necessarily imply that positive $\mathrm{mAb}$ recognise the identical $\mathrm{CD}$ in swine $[33,171]$.

\section{LYMPHOID AND MYELOID CELLS}

\subsection{Markers of $T$ and/or NK (natural killer) cells}

\subsubsection{CD2}

Swine CD2 (LFA2), a $50 \mathrm{kDa}$ type I transmembrane glycoprotein ${ }^{2}$ [167] is an adhesion molecule, the ligand of which LFA-3 (CD58) is found on many cells [34]. It is originally the sheep red blood cell receptor [167] and the anti-CD2 mAb block formation of the T-cell rosette [83]. In peripheral blood, most of the TcR- $\alpha \beta \mathrm{T}$ cells express CD2, like $\mathrm{CD} 2^{+} \mathrm{CD} 4^{+} \mathrm{CD} 8^{-}, \mathrm{CD} 2^{+} \mathrm{CD} 4^{+} \mathrm{CD} 8^{\text {low }}$, $\mathrm{CD} 2{ }^{+} \mathrm{CD} 8^{\text {low }} \mathrm{CD} 4^{-}, \mathrm{CD} 2^{+} \mathrm{CD} 8^{\text {high }} \mathrm{CD} 4^{-}$, in contrast to $\mathrm{TcR}-\gamma \delta \mathrm{T}$ cells which are $\mathrm{CD} 2^{-} \mathrm{CD} 4^{-} \mathrm{CD}^{-}, \mathrm{CD}^{+} \mathrm{CD} 4^{-} \mathrm{CD} 8^{\text {low }}$ and $\mathrm{CD} 2^{+} \mathrm{CD}^{-} \mathrm{CD}^{-}[92,168,239]$; in addition, there is a large proportion of non- $\mathrm{T}\left(\mathrm{CD}^{-}\right)$, non-B (sIg-) lymphocytes expressing CD2, $\left(\mathrm{CD} 2^{+} \mathrm{CD} 4^{-} \mathrm{CD} 8^{\text {low }}\right)$ and exhibiting a natural killer activity [239], as well as a subset of B lymphocytes albeit with CD2 at low level [196]. In foetus cells with a high level of MHC (major histocompatibility complex) class II and a low level of CD2 and CD25 expression may represent B cell precursors [194, 197]. On the contrary, in the spleen, most TcR- $\gamma \delta \mathrm{T}$ cells express CD2 and/or CD8 ${ }^{\text {low }}$ whilst in the blood the majority of TcR- $\gamma \delta$ T cells are CD2 ${ }^{-} \mathrm{CD} 8^{-}$[239].

\subsubsection{CD3-T cell complex}

The CD3-TcR is a multi-polypeptide membrane complex on T lymphocytes that is composed of the highly variable, antigen-binding

${ }^{2}$ The Human Protein Reference Database [online] http://www.hprd.org/ [consulted 08/04/2008] and Human Cell Differentiation Molecules (HCDM) [online] http://www.hcdm.org/ [consulted 08/04/ 2008] also provide background information on protein structure, function and expression.

Page 4 of 28 (page number not for citation purpose)
TcR heterodimer $(\alpha \beta$ or $\gamma \delta)$ and invariant signalling CD3 peptide chains [113]. However, the assembly of the CD3 complex on $\gamma \delta \mathrm{T}$ cells is probably more complex, since unlike the conventional anti-CD3, the $\mathrm{mAb}$ anti-purified porcine CD3 molecule of $\gamma \delta \mathrm{T}$ cells reacted specifically with peripheral $\gamma \delta$ $\mathrm{T}$ cells but not with $\alpha \beta$ T cells and failed to induce antigenic modulation, $\mathrm{T}$ cell proliferation and CD3-redirected cytotoxicity [243]. However, no anti-pig $\alpha \beta \mathrm{T}$ cell mAb have been produced. The NK cells are enriched in the $\mathrm{CD}^{-}{ }^{-} \mathrm{CD} 21^{-} \mathrm{CD} 172 \mathrm{a}^{-}$fraction [150] and their activities stimulated by IL-2/IL-12/IL-18 cytokine, inducing IFN-gamma, perforin production and cytotoxicity against target cells.

\subsubsection{1. $C D 3 \varepsilon$}

The porcine $\mathrm{CD} 3 \varepsilon$ chain has been cloned, sequenced and transiently expressed in COS cells (cells being CV-1 (simian) in Origin, and carrying the SV40 genetic material) [111]. A panel of $14 \mathrm{mAb}$ (PPT 1-14) directed against the porcine CD3 molecule [142, 238] defines six groups of $\mathrm{CD} 3 \varepsilon$ epitopes; they coprecipitate two types of TcR expressed on the surface of TcR- $\alpha \beta$ and TcR- $\gamma \delta$ T cells which differ in antigenicity, signal transduction potential and structure. They revealed that the density of $\mathrm{CD} 3$ on $\mathrm{CD}^{+}{ }^{+}$or $\mathrm{CD}^{+}$cells is relatively low and heterogeneous, whereas the $\mathrm{CD} 2^{-}, \mathrm{CD} 8^{-}$ or $\mathrm{SWC6}^{+} \mathrm{T}$ cells express CD3 at a higher and more homogeneous level [238]. Based on differing mitogenic effects, the 14 anti-CD3 $\mathrm{mAb}$ can be divided into three groups [241] (a) PPT3 requires both epitope ligation and some unknown additional signal(s); (b) PPT5, 6, 9, 12 , etc. only requires epitope ligation, either by monocytes or by immobilisation; (c) PPT7 requires neither epitope ligation nor participation of APC (Ag-presenting cells).

\subsubsection{TcR $\delta$ and $\gamma$-chain}

Biochemical analysis revealed that one TcR $\delta$-chain of $40 \mathrm{kDa} \mathrm{MW}$ and three distinct TcR $\gamma$-chains of 37,38 and $46 \mathrm{kDa}$ MW are distributed in different subsets of porcine $\gamma \delta$ T cells $[92,168,221]$. 
MAb immunoprecipitating heterodimers of 37 and $40 \mathrm{kDa}$ MW [60, 61, 242] recognised a constant region of the $\delta$-chain [61] and first demonstrated that the majority of 'null cells' $\left(\mathrm{CD} 2^{-} \mathrm{sIg}^{-}\right)$are $\mathrm{TcR}-\gamma \delta \mathrm{T}$ cells $[23,243]$. Some other $\mathrm{mAb}$ recognise different epitopes of the $\gamma$-chain [61], whereas 7G3 was demonstrated suitable for high-quality immunostaining on frozen sections [218]. In addition, PG83A and $86 \mathrm{D}$ specifically recognise the porcine $\gamma$-chain of the TcR [61]. Furthermore the expression of a phylogenetically conserved external epitope of TcR $-\gamma \delta$ subdivides porcine $\gamma \delta \mathrm{T}$ cell lymphocytes into a minor $86 \mathrm{D}^{+}$and a major $86 \mathrm{D}^{-}$subset [92].

\subsection{Markers of TcR- $\gamma \delta$ T cells and 'null cells'}

In swine, as well as in ruminants, there is a high proportion of null cells $(\geq 30 \%$ in the blood of piglets $[134,180])$. These cells were originally defined as cells which did not form a rosette with sheep red blood cells - thus devoid of CD2 and of membrane immunoglobulin (CD2- sIglymphocytes) [25, 180]. One population is similar in phenotype and distribution to the population identified in other mammals. The second population is distinguished by expression of WC1. Analysis of these two populations of $\gamma \delta \mathrm{T}$ cells have shown they differ in expression of other lineage restricted molecules as well, including CD2, CD6, CD8 and molecules with no known human or rodent equivalent [60].

It is now clear that this intriguing cell population comprises several distinct subsets encompassing $\gamma \delta \mathrm{T}$ cells, although not all $\gamma \delta \mathrm{T}$ cells are null cells. In fact, $\mathrm{CD}^{+}$ $\mathrm{CD} 2^{-} \mathrm{CD} 4^{-} \mathrm{CD}^{-}, \mathrm{CD}^{+} \mathrm{CD} 2^{+} \mathrm{CD} 4^{-} \mathrm{CD} 8^{\text {low }}$ and $\mathrm{CD}^{+}{ }^{+} \mathrm{CD} 2^{+} \mathrm{CD} 4^{-} \mathrm{CD} 8^{-} \gamma \delta \mathrm{T}$ cell subsets have been identified [216]. Interestingly, a subset of these circulating $\gamma \delta \mathrm{T}$ cells displays a phenotype similar to professional antigen presenting cells and are able to take up and present soluble antigen to $\mathrm{CD}^{+}{ }^{+} \mathrm{T}$ cells in a direct cell-cell interaction via $\mathrm{MHC}$ class II [217].

\subsubsection{SWC4, SWC5 and SWC6}

MAb that form the SWC4 cluster immunoprecipitate two heterodimeric molecules of $270-280 \mathrm{kDa}$, the largest of which is also recognised by the anti-SWC6 $\mathrm{mAb}$. They label the majority of 'null' (CD2- $\left.\mathrm{SIg}^{-}\right)$lymphocytes $[23,25,60,61]$.

MAb against SWC5 [24, 61] also bind to determinants found on null lymphocytes.

A single mAb Mac320 defines SWC6, a disulphide-linked heterodimer that is present in two isoforms of 270 and $280 \mathrm{kDa}$. In reducing conditions, it immunoprecipitated 2 or 3 polypeptide chains at $130-160 \mathrm{kDa}$ MW the largest of which is also precipitated by MAC319 assigned as anti-SWC4 mAb $[25,61]$. It effectively identifies all null T lymphocytes in the blood and the majority of these $\mathrm{SWC6}^{+}$cells also express the orthologue of WC1 $[25,60]$. The second population is negative for SWC4, SWC5 and SWC6 and similar in phenotype and distribution to the $\mathrm{WC}^{-}$population in cattle [59] but expresses CD2 and CD6. A subset coexpresses CD8. As in cattle, this population is low in concentration in peripheral blood and most lymphoid organs but high in the spleen [61].

\subsubsection{Anti-WC1}

The anti-bovine WC1 mAb CC101 recognises a conserved determinant of $\mathrm{WC1}$ of sheep and cattle and cross-reacts with porcine lymphocytes [24,61]. While WC1 is expressed on the majority of ruminant $\gamma \delta$ T cells only the $\mathrm{CD} 2^{-}$subset of porcine $\gamma \delta \mathrm{T}$ cells are labeled [44]. Porcine WC1 was identified as a new member of the scavenger-receptor cysteine-rich (SRCR) superfamily containing up to six extra-cellular SRCR domains, and being highly homologous to other members of the family. Interestingly, a striking feature of the porcine and ruminant $\mathrm{WC} 1$ gene is its presence as a multigene family with extensive sequence diversity, both at the nucleotide and predicted protein levels [101]. 


\subsection{Accessory molecules}

\subsubsection{CD4}

CD4 is expressed on $50 \%$ of thymocytes and extra-thymic Th (helper $\mathrm{T}$ cells) lymphocytes [144]. Furthermore, blood plasmacytoid DC (dendritic cells) (or NIPC natural interferon-producing cells) express high levels of CD4 in contrast to conventional (myeloid) DC [208]. Anti-CD4a epitope antibodies inhibit binding to MHC class II and block the activation of Th lymphocytes [140, 144].

CD4/CD8 double-positive (DP) lymphocytes were found to increase gradually in proportion with age (30-55\% by 3 years of age) and were able to proliferate in response to stimulation with recall viral antigen consistent with the hypothesis that this population in swine includes memory/effector $\mathrm{T}$ cells [52, 173, 177, 248, 249].

Interestingly, a novel antigen recognised by mAb 2E3 is selectively expressed in the periphery by a subset of porcine $\mathrm{CD} 4{ }^{+} \mathrm{T}$ cells, on both $\mathrm{CD} 4{ }^{+} \mathrm{CD} 8 \alpha^{-}$and $\mathrm{CD} 4{ }^{+} \mathrm{CD} 8 \alpha^{\text {low }}$. $\mathrm{CD} 4^{+} 2 \mathrm{E} 3^{+} \mathrm{T}$ cells show phenotypical and functional characteristics of naive $\mathrm{T}$ cells with the majority of them being CD29 ${ }^{\text {low }}$ CD45RA ${ }^{\text {high }}$ CD49 ${ }^{\text {low }}$ [152]. Accordingly, after mitogen activation $\mathrm{CD}^{+} 2 \mathrm{E} 3^{+} \mathrm{T}$ cells express high levels of IL-2 mRNA, but only traces of IFN- $\gamma$ or IL-4 mRNA.

\subsection{2. $C D 5$}

CD5 is expressed on most thymocytes (92-97\%), both immature and mature thymocytes at low and high levels respectively on 54-97\% of peripheral blood T lymphocytes [161] with a heterogeneous distribution [166]; high levels of CD5 are found on $\mathrm{CD}^{+}{ }^{+} \mathrm{Th}$ cells, $\mathrm{CD} 4^{+} \mathrm{CD} 8^{+}$memory $\mathrm{T}$ cells and $\mathrm{CD}^{-}{ }^{-} \mathrm{CD} 8^{\text {high }} \mathrm{Tc}$ ( $\mathrm{T}$ cytotoxic) cells. In contrast, $\mathrm{CD} 4^{-} \mathrm{CD} 8^{-} \mathrm{CD} 2^{-} \gamma \delta \mathrm{T}$ cells express low levels while $\mathrm{CD} 4^{-} \mathrm{CD} 8^{-}$and CD4 ${ }^{-} \mathrm{CD} 8^{\text {low }} \mathrm{NK}$ cells do not express CD5.

Thus, CD5 can also be used to distinguish MHC class I-restricted cytolytic $\mathrm{T}$ cells $\left(\mathrm{CD}^{-} \mathrm{CD}^{+} \mathrm{CD}^{+}\right)$from $\mathrm{MHC}-$ unrestricted, spontaneous cytotoxic NK cells $\left(\mathrm{CD}^{-} \mathrm{CD}^{-} \mathrm{CD}^{+}\right)$[138]. In addition,
10-30\% of porcine blood B lymphocytes are $\mathrm{CD}^{+}$of low density [161]. This population could represent the $\mathrm{B} 1$ cells of mice, man and other species based on frequency and lymphoid organ distribution and the high frequency in neonates [7].

\subsubsection{CD6}

The homologous of human CD6 [159] has three cystein-rich domains and belongs to the family of SRCR as CD5 and other peptidebinding receptors $[135,138]$. Differences in $\mathrm{N}$ - and O-glycosylation sites may account for variations in MW between porcine CD6 molecules.

All thymocytes with the exception of $\mathrm{CD}^{-} \mathrm{CD}^{-}$cells, and $39-76 \%$ of peripheral blood T cells express CD6. CD6 is coexpressed with $\mathrm{CD}^{+}{ }^{+} \mathrm{CD} 8^{-}$Th cells and CD4 $4^{-} \mathrm{CD}^{\text {high }}$ Tc cells whereas $\mathrm{CD} 4^{-} \mathrm{CD} 8^{\text {low }}$ and $\mathrm{CD}^{-} \mathrm{CD}^{-} \gamma \delta \mathrm{T}$ are devoid of CD6. Thus, $\mathrm{CD}^{+} \mathrm{T}$ lymphocytes are responsible for MHC class I-restricted T-cell cytotoxicity (TcR $\alpha \beta$ ) whereas the $\mathrm{CD}^{-} \mathrm{T}$ lymphocytes support spontaneous and un-restricted MHC cytotoxicity $[138,173]$. CD6 is not expressed nor by $B$ cells nor by cells of the myeloid lineage.

\subsection{4. $C D 8$}

CD8 is expressed as a homo-dimer $(\alpha \alpha)$ or a hetero-dimer $(\alpha \beta)$ [97, 144]. CD8 $\alpha$ is expressed on the surface of most thymocytes, and is present at high $\left(\mathrm{CD} 8 \alpha^{\text {high }}\right)$ or low $\left(\mathrm{CD} 8 \alpha^{\text {low }}\right)$ cell density on porcine $\mathrm{T}$ cells. $\mathrm{CD} 8 \alpha^{\text {high }}$ cells are generally Tc cells whereas the co-expression of low levels of CD8 $\alpha$ with $\mathrm{CD}^{+}$identifies memory Th cells $[145$, $146,175,177,246]$. Most $\gamma \delta \mathrm{T}$ cells are $\mathrm{CD}^{-}$with a minor subset $\mathrm{CD} 8 \alpha^{\text {low }}[239$, 240]. The mAb specific for the $\beta$-chain can be used to distinguish between $\mathrm{CD} 8^{\text {low }}$ and CD8 ${ }^{\text {high }}$ cells, with only the latter expressing CD8 $\beta$ [251]. MAb directed against the CD8a or b epitopes, block cell-mediated lysis in allogeneic $\mathrm{T}$ cell responses [97, 144, 162]. $\mathrm{MAb}$ that recognise the wCD8c epitope bind to only the $\mathrm{CD} 4^{-} \mathrm{CD} 8 \alpha^{\text {high }}$ representing the 
classical Tc cells and not the $\mathrm{CD} 4{ }^{+} \mathrm{CD} 8 \alpha^{\text {low }}$ DP (double positive) Th-cell subset [251].

\subsection{5. $S W C 2$}

SWC2 cluster closely to the CD6 group $[162,170]$. The role of these molecules of $49-51 \mathrm{kDa}$ [162] still remains unknown.

\subsection{Differentiation antigens of $B$ cells}

B cells in mammals are lymphocytes that mature in the bone marrow and/or ileal Peyer patch [41] and, when stimulated by free antigen in solution, differentiate into plasma cells that secrete immunoglobulins (Ig) that inactivate/eliminate the antigens. This population is characterised by expression of the $\mathrm{BcR}$ representing a stable (i.e. not elutable) membrane immunoglobulin [180] that can be recognised by antibodies against the $\mathrm{Ig}$ light chain [193]. Extensive work on the antibody repertoire development was done and reviewed by the Butler laboratory [42].

\subsection{1. $C D 1$}

MAb anti-CD1 antibody 76-7-4 [86] recognises the product of porcine pCD1. One gene, a class I-like protein, with a $40 \mathrm{kDa}$ heavy chain and a $12 \mathrm{kDa}$ light chain [86], thus highly similar to human CD1a [55]. In both humans and pigs, CD1 group I (CD1 a, b and c) markers are expressed on cortical thymocytes, a fraction of $\mathrm{B}$ cells, thymic dendritic cells, some macrophages and Langerhans cells [147, 167, 183].

\subsection{2. $w C D 21$ (complement receptor 2, CR2)}

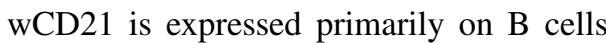
and follicular dendritic cells. It is recognised by the mAb IAH-CCR1, a cross-reacting anti-bovine CD21 [133, 171], BB6-11C9, and C35 [29, 63]. The broad species-overlapping reactivity of $\mathrm{mAb}$ directed against $\mathrm{CD} 21$ as well as CD9, CD11, CD14, CD18, CD29, CD44, CD45, CD47, CD49d, CD61, CD86, CD91, CD172a, is interesting, indicating evolutionary highly conserved epitopes on these surface molecules but reactivity alone is not sufficient. These data have to be confirmed by molecular analyses, e.g. immunoprecipitation studies and/or analyses on transfectants [171].

\subsection{3. $S W C 7$}

SWC7 is expressed on a subset of B cells and on follicular dendritic cells in the germinal centers of different lymphoid organs (tonsil, lymph-node, spleen, Peyer patches [37]) and on a large fraction of $B$ cells in the thymus and bone marrow [192]; but it is not expressed on resting circulation B cells [37]. Nevertheless, after phorbol ester activation, SWC7 is induced on most blood B cells and on a subset of T cells [37, 192].

Although anti-SWC7 mAb are related to bovine CD19 according to patterns of flow cytometry profiles these $\mathrm{mAb}$ immunoprecipitate a $40 \mathrm{kDa}$ molecule instead of the expected $90 \mathrm{kDa}$ molecule $[62,63]$.

\subsubsection{Cross-reacting anti-human (anti-h) B cell $m A b$}

\subsubsection{1. $C D 19$}

CD19 is a type I transmembrane protein of the immunoglobulin super family (IgSF). It is present on $\mathrm{B}$ lymphocytes but not plasma cells and it is a co-receptor involved in B cell signalling. The swine CD19 gene has been cloned, sequenced and expressed in bacteria; only $60 \%$ sequence similarity was in the extracellular region explaining that only one of 17 anti-hCD19 mAb recognised swine B cells (B-D3 from Diaclone reactivity with CD19 to T1) [212].

\subsubsection{2. $C D 79$}

Human CD79a and CD79b are two small $22 \mathrm{kDa}$ type I IgSF proteins that are associated with the BCR. The commercial mAb antihuman $\mathrm{CD} 79 \alpha$ seems to label the intracellular portion of the swine molecule in cytometry but not in immunohistochemistry [75]. It is claimed as a pan-B cell but as ascertained by phenotypes warrants further confirmation. 


\subsubsection{3. $C D 72$}

Swine CD72 is highly transcribed in the lymph-node, thymus, lung tissues and pulmonary alveolar macrophages, perhaps due to the known expression of this gene into $\mathrm{B}$ cells, some $\mathrm{T}$ cell macrophages and $\mathrm{DC}$ cells [18]. Compared to CD72 sequences from other species, the extracellular part of the swine polypeptide is less conserved than the intracellular part, explaining the absence of identified cross-reacting mAb [18].

\subsection{Differentiation antigens of monocytes, macrophages and dendritic cells}

\subsection{1. $C D 14$}

Swine CD14 is a marker of monocytes and macrophages $[68,85,209,220]$ with a maturation-dependent expression for the monocytic-bone marrow haematopoietic cell population [210]. The intensity of CD14 labelling depends on the cell type: PMN (polymorph nuclear leukocytes) neutrophils express low levels of CD14, whereas monocytes/macrophages (macrophages less than monocytes [128]) express higher levels of CD14. CD14 can also be found on monocyteand bone marrow-derived GM-CSF-driven DC, although functional differences are found when compared to monocyte CD14. Furthermore, the continued presence of CD14 and CD16 [87] on mature and immature porcine DC was a notable difference with other species including humans [46].

The mAb anti-hCD14 cross-react with porcine CD14 expressed on alveolar macrophages [107], on 60-70\% swine monocytes but few granulocytes (6-13\%) [69]. Inversely $\mathrm{mAb}$ anti-swine CD14 cross-react with human monocytes and granulocytes, in a pattern similar to that of human CD14 [209]. The gene encoding CD14 has been recently cloned in swine [148], showing that the different reactivity patterns described by anti-CD14 $\mathrm{mAb}$ may be due to differences in affinity of these antibodies [68].

\subsubsection{CD16}

The CD16 gene has been cloned, and the gene product is recognised by the mAb G7 [57, $82,109,214]$. MAb has been shown to abolish PBL (porcine blood leukocytes)-mediated Abdependent cellular cytotoxicity almost entirely and to inhibit PMN-mediated Ab-dependent cellular cytotoxicity by about $50 \%$ [232]. All blood monocytes and all NK lymphocytes bear CD16 [185, 232]. This receptor is also found on immature and mature monocyte-derived DC as well as on blood DC in pigs, contrasting to the human expression pattern [46] and in gut DC [87].

\subsection{3. $C D 123$}

CD123, a type I cytokine receptor family, associates with the common CD131 signalling chain. CD123 is expressed on haematopoietic progenitors and most myeloid cells including basophiles and mast cells. Although no CD123 cross-reactive mAb was identified, the molecule can be detected using his-tagged IL-3 [208]. IL-3 is required for the survival of the DC subset as blood myeloid DC and NIPC, the latter expressing particularly high levels of this receptor [208].

\subsection{4. $C D 163$}

The mAb anti-swine CD163 recognises a $120 \mathrm{kDa}$ protein with a sequence similar to that of human CD163 [38, 185, 220]. This receptor is restricted to cells of the porcine monocyte/macrophage lineage and more specifically, to macrophages and tissue DC [53] and confers susceptibility to PRRSV [43]. CD163 ${ }^{+}$monocytes produce more TNF- $\alpha$, express high levels of adhesion molecules and are better at presenting antigens to $\mathrm{T}$ cells when compared to $\mathrm{CD} 163^{-}$ monocytes [48]. In addition, the DC derived from $\mathrm{CD}_{163}{ }^{+}$monocytes, express higher levels of MHC class II and CD80/86 and are more efficient antigen presenting cells [49]. 


\subsubsection{CD172a}

CD172a, an $\alpha$ member of SIRP (signal regulatory protein) of $90-115 \mathrm{kDa} \mathrm{MW}[4,5]$ also known as CD172a [28, 147, 220] is associated with the protein-tyrosine phosphatase SHP-1 after tyrosine phosphorylation. This cluster is present on monocytes/macrophages, neutrophils [86], bone-marrow derived DC, blood monocyte-derived DC and plasmacytoid DC [46], thymic DC [181] skin DC [14] gut DC $[21,90]$ and as NIPC $[126,155]$. Monocytes express high levels of CD172a, whereas the two blood DC, conventional and plasmacytoid DC express only low levels [208].

\subsection{6. $C D 203$}

Swine CD203, (SWC9) of 130 and $>205 \mathrm{kDa} \mathrm{MW}$ is orthologue of human CD203a (NPP1/CD203a) [148]. It is present on thymocytes but disappears during $\mathrm{T}$ cell development, since most mature peripheral lymphocytes do not express this marker. As monocytes differentiate into macrophages, they rapidly start to express CD203 [12]. On this basis, CD203 has been proposed as a useful marker for studies of myeloid differentiation or maturation. Most prominent expression of CD203a was found in lung macrophages and liver sinusoids.

\subsection{7. $S W C 8$}

SWC8 $[85,91]$ is present on all PMN cells in blood, macrophages and PMN cells in the gut lamina propria [220]. This antigen is not restricted to $\mathrm{CD} 172 \mathrm{a}^{+}$myeloid cells, since MIL3 also labels B cells, a subset of CD $8^{\text {high }}$ $\mathrm{T}$ cells, epithelial and fibroblastic cells [91]. SWC8 has been used to discriminate blood and bone-marrow granulocytes $\left(\mathrm{SWC}^{+}\right)$ from monocytes $\left(\mathrm{SWC}^{-}\right)$. This epitope is associated with the differentiation of cells, such as monocytes and macrophages [192]. A minor fraction of $\mathrm{CD}^{+}{ }^{+} \mathrm{T}$ cells also expresses this antigen at a low level [91]. Through SWC3/SWC8 double-labelling, three cell populations committed to the myeloid lineage can be discriminated: (i) early myeloid progenitors are $\mathrm{CD} 172 \mathrm{a}^{\text {low }} \mathrm{SWC}^{-}$; (ii) cells committed to the granulocytic lineage are

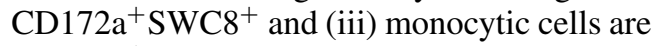
CD172a ${ }^{+}$SWC8 $^{-}$[210].

\subsubsection{Other anti-macrophage $m A b$}

Two mAb (clones 2G6 and 2B10) directed against porcine macrophages [17], immunoprecipitating under non-reducing conditions a $140-150 \mathrm{kDa}$ and a $140-145 \mathrm{kDa}$ antigen, respectively, identify cell populations of the mononuclear phagocytic system. While 2G6 detected tissue macrophages, 2B10 stained scattered cells in the lymph node and in the lung interstitium.

\subsection{Differentiation antigen of activated cells}

CD25 is expressed on activated $\mathrm{T}$ and B lymphocytes [11, 143] and on regulatory $\mathrm{T}$ cells $[29,103]$ (personal communication, C. LeGuern $^{3}$ ).

\subsection{Common $\mathbf{T}$ or $\mathrm{B}$ cell $\mathrm{Ag}$}

\subsubsection{CD45 and CD45R}

As in almost all species, anti-CD45 antibodies recognise common epitopes present in all isoforms (named CD45), whereas anti-CD45R antibodies react with restricted antigenic determinants CD45RA, CD45RB or CD45RC encoded by exons $\mathrm{A}, \mathrm{B}$ and $\mathrm{C}$ displaying alternative splicing. The isoform devoid of all these antigenic determinants is called CD45RO.

MAb anti-CD45 (or leukocyte common antigen) were based on their broad reactivity patterns with lymphoid and myeloid cells and their ability to immunoprecipitate three polypeptides with an apparent MW of 226, 210 and $190 \mathrm{kDa}$ whereas $\mathrm{mAb}$ antiCD45R were based on their restricted reactivity against lymphoid and myeloid target cells, and their ability to immunoprecipitate either

\footnotetext{
${ }^{3}$ LeGuern C., Role of MHC Class II in regulatory tolerance to class II-matched transplants, Transplantation Biology Research Center, Massachusetts General Hospital and Harvard Medical School, Boston, MA 02129, USA.
} 
two polypeptides with an apparent molecular weight of 226 and $210 \mathrm{kDa}$ or a single polypeptide with an apparent molecular weight of $210 \mathrm{kDa}$ [52,247].

As a prelude to defining the specificity of anti-porcine CD45 mAb for this purpose, Chinese hamster ovary cells were transfected with constructs containing cDNA encoding the extracellular and transmembrane domains of four pig CD45 isoforms, CD45RO, CD45RC, CD45RAC and CD45RA [188].

CD45 is present on more than $95 \%$ of PBL, $90 \%$ of thymocytes and $95 \%$ of granulocytes and monocytes in pigs. CD45RA (exon A) reacted with $65-85 \%$ of PBL and only $25 \%$ of thymocytes, but is absent from granulocytes [250]. Only between $10 \%$ and $50 \%$ of monocytes express this marker. All B cells express CD45RA, whereas most $\mathrm{CD}^{+}$ $\mathrm{T}$ cells express this marker only weakly (ten times lower), if at all. A reverse pattern was observed with CD45RC (exon C): a significant proportion of $\mathrm{CD}^{+}{ }^{+} \mathrm{T}$ cells was stained at a level 10 times higher than that of B cells whereas in humans it is the CD45RB which is expressed at a high level onto $\mathrm{CD}^{+} \mathrm{T}$ cells [250]. In mice and humans, CD45RA identifies naive cells whereas CD45RO (i.e. an isoform devoid of all these antigenic determinants) identifies memory cells. Accordingly, CD45RA is gradually down-regulated after the stimulation of swine $\mathrm{T}$ cells with a mitogen $[39,70]$. The polymorphism of CD45 was used to detect donor lymphocytes during migration experiments [20,26].

\subsection{2. $S W C 1$}

SWC1 has two subunits, of 41 and about $15 \mathrm{kDa}$, under reducing conditions [124, 169]. SWC1 is expressed on thymocytes [163], resting $\mathrm{T}$ cells, monocytes and neutrophils but is absent from B lymphocytes [144]. This relates to the observation that monocytes gradually downregulate SWC1 during their differentiation to macrophages [12]. Similarly, T lymphocytes also down-regulated SWC1 expression following in vitro activation [163].

\subsection{Costimulatory molecules}

\subsection{1. $w C D 40$}

Human mAb CD40 cross-react with porcine cells and show similar cellular reactivity onto B cells, B cell line L14, pulmonary alveolar macrophages and endothelial cells with increased expression on activated cells [29]; however the MW reported by the mAb STH224 of $35 \mathrm{kDa}$ is lower than that reported for human CD40 $(48 \mathrm{kDa})$, and one-color flow cytometry results of PBMC and mesenteric lymph node (MLN) cells showed only partial co-expression of the ligands, hence wCD49 $[19,29,86]$. Cholera toxin promoted the development of semi-mature DC phenotype with decreased levels of MHC class II and CD40, but increased CD80/86 expression [19]. Porcine membrane CD40L, a ligand of the CD40 receptor, was cloned and sequenced [231] with $88 \%$ AA sequence similarity to human CD40L. Human soluble CD40L may be used to stimulate the $\mathrm{CD} 40^{+}$ swine cells [16].

\subsubsection{CD69}

Swine CD69 mRNA was detected in activated PBL, NK cells, macrophages, monocytes and granulocytes, but not in resting cells. These results indicate that CD69 can be used as an activation marker in pig cells of innate as well as acquired immune systems [244]. No antibody against porcine CD69 is yet available.

\subsubsection{CD80/86 and CTLA-4 (CD152)}

Porcine co-stimulatory molecules CD86 (also known as B7-2) soluble ([74] or transmembrane [54, 125] and CD80 (also known as B7-1) soluble [58] or transmembrane [215, 228] have been characterised molecularly, structurally and functionally, as well as their porcine receptor CTLA-4 (CD152) [226]. Sequence analysis showed a high degree of conservation in residues involved in pCD80/86 with hCD28 and CTLA-4 so that to detect expression of CD86, human CTLA-4 $\mathrm{mu}-\mathrm{Ig}$ fusion protein was used [19, 132]. 
Cross-reacting anti-hCD80 blocks the stimulation of human lymphocytes by porcine splenic lymphocytes [215].

\subsection{Cell adhesion molecules}

Adhesion molecules belong to four main protein families, integrins, selectins and proteoglycans and members of the immunoglobulin superfamily. In this chapter, we will focus on adhesion molecules more specifically implicated in leukocyte trafficking [20] and susceptible to play a role in xenotransplantation $[71,187,191]$.

\subsubsection{Molecules of the integrin family}

Integrin heterodimers composed of noncovalently linked $\alpha$ and $\beta$ transmembrane subunits act as cell surface receptors that mediate cell-cell interactions and attachment to the endothelium.

\subsubsection{The $\beta 2$ integrin subfamily CD11a-c/CD18}

MAb anti-hCD18 or anti-pCD18 [109] recognise an epitope CD18a on the common integrin $\beta 2$-chain (CD18, $95 \mathrm{kDa})$ and react with $80-96 \%$ of porcine PBMC and PMN. In association with CD11a (180 kDa), CD11b (170 kDa) or CD11c $150 \mathrm{kDa}$ ) CD18 form the heterodimers CD11a/CD18, CD11b/CD18, CD11c/CD18 which differ in their pattern of expression and in cellular distribution as compared to humans [67,220].

\subsection{CD11a/CD18}

CD11a, (LFA-1, lymphocyte-functional antigen-1) is found on all leukocytes with high levels on monocytes, granulocytes and a $\mathrm{CD}^{+}$subset but low levels on $\mathrm{B}$ cells and various levels inversely correlated with CD3 expression on $\mathrm{T}$ cells, CD $3^{\text {low }} \mathrm{CD} 11 \mathrm{a}^{\text {high }}$ and $C D 3^{\text {high }} \mathrm{CD} 11 \mathrm{a}^{\text {low }}$ [3]. Memory Th cells $\left(\mathrm{CD}_{45 \mathrm{RA}^{-}}\right)$express higher levels of CD11a than naive $\mathrm{T}$ cells probably in relation to their greater capacity to migrate from the lymphoid tissues to inflammatory sites [3]. $\mathrm{MAb}$ anti-CD11a inhibit the ConA mitogenic response, the NK cell-cell mediated lysis of K-562 cells and the mixed lymphocyte reaction [3].

\subsubsection{2. $\mathrm{wCD} 11 \mathrm{R} 1 / \mathrm{CD} 18$}

The cross-reactive mAb anti-hCD11b (TGM6-5) had a similar pattern of reactivity to mAb MIL-4 raised against porcine leukocytes [85]: both mAb label $\sim 50 \%$ porcine PMN, all eosinophils, but not monocytes or alveolar macrophages [67, 85, 204, 220], whereas in humans CD11b is expressed on all monocytes and macrophages and granulocytes. Consequently, the molecule recognised by the cross-reactive anti-hCD11b was named wCD11R1. A recent study using the cannulated pseudo-afferent lymph model, has demonstrated that large numbers of DC, expressing CD11R1 (CD11b) and CD172 are found in efferent lymph [21] and are phenotypically similar to DC from the diffuse lymphoid tissue [21,87].

Inversely, $\mathrm{mAb}$ anti-swine $\mathrm{CD} 11 \mathrm{~b}$ defines a cluster of differentiation that corresponds to the expression of $\mathrm{CD} 11 \mathrm{~b}$ similar to that observed on human cells but with a different MW so that they were designed as wCD11R3 [67, 69, 209, 220].

The $\mathrm{CD} 11 \mathrm{~b} / \mathrm{CD} 18$ herodimer binds to a fragment of the complement (iC3b) and contributes to PMN and monocyte adhesion to the endothelium, so that mAb anti-wCD11R3 inhibits phagocytosis of $\mathrm{iC} 3 \mathrm{~b}$ opsonised particles and adherence of activated PMN to plastic [35].

\subsection{CD11c/CD18}

While in humans CD11c is found on all myelo-monocytic cells, NK cells and some T and $\mathrm{B}$ cell subsets, in the pig the distribution with cross-reactive anti-hCD11c is different, with expression on most monocytes but not on granulocytes [67, 86, 204]. Hence, we call the prefix $\mathrm{w}$ for $\mathrm{wCD} 11 \mathrm{R} 2$ recognised by the cross-reactive anti-hCD11c (S-cHl3).

\subsubsection{The $\beta 1$ integrin subfamily, $C D 49$ a-f/CD29 heterodimers: the VLA family}

The structure of CD29 (the $\beta 1$ integrin subunit) is highly conserved among species and 
includes 12 potential $\mathrm{N}$-glycosylation sites. Punctual changes between human and swine CD29 molecules within the ligand binding domain, and/or the regulatory domain suggest potential differences between human and porcine CD29 relative to the human CD29 ligand [94]. CD29 mRNA were expressed in a variety of porcine tissues with different intensities [95] and CD29 integrin is widely distributed and found on all the cell lines tested in one study [91]. The anti-hCD29 mAb cross-react with porcine cells and have been assigned to the wCD29 group due to differences in MW [91]. In immunohistochemistry, rabbit antibody anti-porcine recombinant CD29 displayed a morphological pattern associated with smooth muscle, epithelium and myeloid cells [136].

The CD29 non-covalently associated to one of the six $\alpha$ integrin subunits (CD49 a to $\mathrm{f}$, 150 to $200 \mathrm{kDa}$ ) form the VLA heterodimer, which stands for 'very late activation antigens' reflecting their late upregulation after activation [205].

VLA-4 (the $\alpha 4 \beta 1$ integrins, CD49d/CD29) forms the adhesion molecule, which mediates adhesion to the extracellular matrix components and provides an important stimulus during interactions between $\mathrm{B}$ and $\mathrm{T}$ lymphocytes, or between $\mathrm{Th}$ and Tc cells. Furthermore this adhesion molecule is the major ligand for VCAM-1 (vascular cell adhesion molecule-1), which is expressed on inflamed endothelia and certain endothelial cells of the respiratory tract [30]. In all organs except the Peyer patches, $\alpha 4 \beta 1$ (heterodimer detected by mAb anti-h $\alpha 4 \beta 1$ PAG) has been shown to be more frequently expressed on $\operatorname{sig} \mathrm{A}^{+}$and $\mathrm{CD}^{+} \mathrm{T}$ cells of the pharyngeal than palatine tonsil [31]. Variations in the level of wCD49d expression [9] demonstrate a relationship between the activity of blood and spleen Th cells, but not Tc cells. Ag- or IL-2-activated Th $\mathrm{CD} 25^{+}$ and memory Th cells display higher levels of wCD49d than naive cells. Differences in CD49d expression between blood and lymph node cells, and between Tc cells from different organs, show that CD49d levels are high on blood $\mathrm{T}$ cells emigrating from the lymph nodes and spleen [9]. The antihCD49e (Sam-1) was the only mAb crossreacting with the majority of swine monocytic cells, but not other bone-marrow hematopoietic cells [209].

\subsubsection{3. $\beta 3$ integrin: $C D 61$}

The mAb anti-CD61 [115] shows a broad expression in all tissues of the pig with a strongest expression in epithelial cells from tubules in the kidney [130].

\subsubsection{4. $\beta 7$ integrin}

$\beta 7$ integrin associates non-covalently to $\alpha 4$ to form the homing receptor of $\mathrm{T}$ and $\mathrm{B}$ lymphocytes for the gut-associated lymphoid tissue and mammary gland [30,31,219]. It binds and mediates cell attachment to MAdCAM-1 (mucosal cell adhesion molecule-1) [15]. The $\mathrm{mAb}$ against murine $\beta 7$ integrin and as well as the $\mathrm{mAb}$ against an epitope present on the human $\alpha 4 \beta 7$ dimeric molecule crossreact with $\beta 7$ and $\alpha 4 \beta 7$ in swine $[30,31]$. Similar to murine studies, retinoic acid also mediates the induction of $\alpha 4 \beta 7$ on porcine lymphocytes [186].

\subsubsection{Selectins}

Selectins (L-, E-, and P-selectins) belong to a family of cell adhesion molecules and are type I transmembrane proteins with a lectin, an epidermal growth factor and variable numbers of SCR (short consensus repeat) domains. Initial leukocyte rolling on the vascular endothelium is mediated by selectins.

\subsubsection{L-selectin}

L-selectin, CD62L or leukocyte endothelial cell adhesion molecule-1 (LECAM-1) is a glycoprotein that is constitutively expressed and functional on all leukocytes. An antibody directed anti-h L-selectin LAM1-3 ([102] labels porcine lymphocytes [31]. L-selectin ligands include glycosylated cell adhesion molecule-1 (Glycam-1), glycosylated MadCAM-1 and CD34, a sialomucin 
of $120 \mathrm{kDa}$ which is expressed on vascular endothelial cells and appears as the swine L-selectin binding receptor [190]. MECA-79, an anti-rat $\mathrm{mAb}$ reacting with peripheral node addressin (the counter-receptor for L-selectin on lymph node high endothelium venules), cross-react with porcine lymph node high endothelium venules $[31,230]$.

\subsubsection{P-selectin}

P-selectin, CD62P or platelet granule membrane protein-40 is stored preformed in endothelial cells. The porcine P-selectin cDNA has been cloned and used to generate $\mathrm{mAb} 12 \mathrm{C} 5$ [206]. The high degree of conservation of this lectin and EGF domain - particularly in regions involved in ligand binding - explains the ability of human leukocytes to bind to P-selectin. MAb antihP-selectin (G3) cross-reacts with porcine P-selectin and labels 30-60\% of blood macrophages and granulocytes [114].

\subsubsection{E-selectin}

Swine E-selectin, CD62E or ELAM-1 is a glycoprotein of $92 \mathrm{kDa}$ and $71 \%$ homologous with human E-selectin but missing SCR. It is recognised by the human cross-reacting $\mathrm{mAb} 12 \mathrm{~B} 6$ [105, 224]. It is expressed on the activated vascular endothelium, and mediates attachment of neutrophils, monocytes and some lymphocytes [27, 112,224].

\subsubsection{Molecules of the immunoglobulin superfamily}

The immunoglobulin superfamily adhesion molecules are involved in leukocyteendothelial cell interactions. These proteins include ICAM (intercellular adhesion molecule), VCAM-1 and PECAM-1 (platelet endothelial cell adhesion molecule). ICAM-1, -2 and -3 are a group of type I transmembrane molecules within the IgSF having a variable number of Ig constant region-like domains, which are expressed by endothelial cells and bind to the $\beta 2$ (leukocytes) integrins, LFA-1 and Mac-I.

\subsubsection{ICAM}

In swine, the gene structure and endothelial expression of pig ICAM-2 (CD102) are strikingly similar to the human and mouse counterparts: mRNA transcripts were detected in cultured pig endothelial cells and in the lung, spleen, kidney, liver and heart [79]. However, in contrast to humans and mice, ICAM-2 is not down-regulated on cultured endothelial cells after treatment with inflammatory cytokines such as IL- $1 \beta$ and TNF- $\alpha$. The mature protein sequence is $55 \%$ identical to human ICAM2 , with conservation of 5 out of 6 residues critical for binding of the human protein to its ligand LFA-1 [79]. The anti-hCD102 mAb (CBR-IC2/2) labels blood leukocytes and T lymphoblasts [114].

Other $\mathrm{mAb}$ directed against human CD54 (ICAM-1, with $\sim 41 \%$ degree of identity between human and porcine ICAM-1 [207]), CD31 (PECAM-1), CD50 (ICAM-3) do not cross-react with pig cells [114]. However, specific mAb anti-swine ICAM-1 have been developed [207]. HEV (high-endothelial venule) express higher levels of ICAM-1 [20].

Similarly, the expression of CD50 (ICAM-3), although ubiquitous for the majority of human leukocytes, was more restricted on pig cells with the cross-reacting anti-hCD50 (HP2/19). Most pig granulocytes were negative, but monocytes were positive and subsets of $\mathrm{T}$ and $\mathrm{B}$ cells showed variable expression. This work illustrates the importance of carrying out a thorough characterisation of reagents raised and characterised for cells of one species for use in another species [86]. However, specific mAb antiswine ICAM-1 have been developed [207].

\subsubsection{VCAM-1}

Porcine VCAM-1 (CD106) has five Ig domains and an overall $77 \%$ homology with the human protein [223]. Several mAb have been developed against porcine VCAM-1 to specifically block leukocyte adhesion in xenografts $[84,131,154]$. It is highly expressed after cytokine activation of cultured vascular endothelial cells $[13,223]$, and by 
skin endothelial cells during inflammatory skin reactions [84]. As a vascular addressin, VCAM-1 is present constitutively in pharyngeal tonsil and lymph-nodes, but neither in the palatine tonsil nor in Peyer patches and intestinal vascular cells [30,31].

\subsection{4. $C D 44$}

Swine CD44 (also known as Pgp-1, Hermes antigen or H-CAM, gp 85) is a type I transmembrane glycoprotein of 80 to $90 \mathrm{kDa}$ MW with a soluble form present in porcine intestinal efferent lymph [235]. Variants exist due to alternative RNA splicing [104]. Four $\mathrm{mAb}$ have been shown to react with the porcine equivalent of human CD44 [236]. The human mAb Z062 recognise another epitope (wCD44a) [247]. CD44 is strongly expressed by nucleated cells (leukocytes, [9] fibroblasts, epithelial cells) but not on red blood cells (at variance with humans, [247]) and platelets. The expression of CD44 in the lymphoid tissues tested appeared to be related to their level of cell migration capacity [234]. Although CD44 has been ascribed as a receptor involved in lymphocyte recirculation by binding to high endothelial venules, cellcell and cell-extracellular matrix interactions, in swine it is not directly involved in such binding [233].

\section{MAJOR HISTOCOMPATIBILITY COMPLEX ANTIGENS (MHC) IN SWINE}

\subsection{Introduction}

$\mathrm{CD}^{+} \alpha \beta \mathrm{T}$ lymphocytes recognise antigens only if they are presented in the MHC context of Ag-presenting cells. The T cell receptor reacts simultaneously with MHC antigenic peptides (MHC-Ag peptides) and with CD4 or CD8 molecules. Depending on their origin and size, antigenic peptides are either presented by MHC-class II and recognised by Th CD4 lymphocytes or presented by MHCclass I and recognised by CD8 Tc lymphocytes. MHC-class I presents antigenic peptides of eight to nine amino-acids following endogenous degradation in the cytosol, whereas
MHC-class II present peptides of 12 to 25 amino-acids following exogenous degradation in phagolysosomes $[65,200]$. Using synthetic pentadecapeptides, classical swine fever virusspecific $\mathrm{T}$ cell epitopes of SLAd/d miniswine were identified. These represent class II- and class I-restricted Th and cytolytic T cell epitopes, respectively [8]. Moreover, foot and mouth disease virus-specific pentapeptides which stimulated class II-restricted Th cells were identified [78] as well as nonameric peptides able to reconstruct the swine SLA class I protein complex [77].

MHC class I is expressed on all cells of the body, except those of the neural system and red blood cells, whereas in the adult, MHC class II is expressed on the surface of APC such as macrophages, B lymphocytes, microglial and dendritic cells [12, 46, 225]. In developing organisms, MHC II expression is also observed on other types of cells such as endothelium cells of blood vessels and thymic epithelial cells [90].

The pig $\mathrm{MHC}^{4}$ or swine leukocyte antigen (SLA) has been mapped on both sides of the centromere of chromosome 7. The SLA complex is about 2000 kilobases (kb) long, with the SLA class II region locus spanning $500 \mathrm{~kb}$ and the SLA class I and SLA class III regions spanning about $1500 \mathrm{~kb}$. Despite their division by the centromere, the spatial relationships between regions II and III and between the well conserved class I and nonclass I are similar to those observed for the human HLA complex [50].

\subsection{Major histocompatibility complex class I}

MHC class $I$ is a dimer ( $\alpha$ and $\beta$ subunits) of non-covalently associated type I transmembrane proteins - the $\alpha(44 \mathrm{kDa})$

\footnotetext{
${ }^{4}$ Table A and text also report information available through websites: for SLA the Immuno Polymorphism Database-MHC (IPD-MHC) website [online] http://www.ebi.ac.uk/ipd/mhc/sla/stats.html [consulted 24/06/2008]; for Swine genome project [online] http://www.ncbi.nlm.nih.gov/sites/entrez? $\mathrm{db}=$ genomeprj\&cmd $=$ Retrieve $\&$ dopt $=$ Overview $\&$ list_uids=10718 [consulted 24/06/08].
} 
and $\beta$ ( $\beta 2$-microglobulin, $12 \mathrm{kDa})$ chains expressed on most nucleated cells.

The classical class-I SLA genes are designated as SLA-1, SLA-2 and SL-3; the non-classical as SLA-6, SLA-7 and SLA-8 and the pseudogene SLA-4, SLA-5, SLA-9 and SLA-11. The SLA-1, SLA-2 and SLA-3 locus are highly polymorphic. For the SLA-1 locus, there are 44 alleles. The SLA-3 locus has 26 alleles and the SLA-2 locus has 46 alleles.

In contrast, the SLA- 6 locus has limited polymorphim. Only two polymorphisms occur within the alpha- 1 or alpha- 2 domains. The limited polymorphism of SLA-6 is similar to the limited polymorphism of 'non-classical' MHC class loci, such as HLA-E, HLA-F and HLA-G in humans [199]. SLA-6 mRNA has been found in many tissues with the highest level found in lymphoid tissue, which is a pattern of expression more similar to HLA-E than to HLA-F or HLA-G [72].

Lunney [119] and Ivanoska et al. [93] summarise the large set of mAb to SLA I and II antigens. Two antibodies [145] react with SLA class I. MAb 74-11-10 is specific for a polymorphic MHC class I determinant (haplotype $\mathrm{d}$ ), and mAb 76-3-2, precipitates two chains of $43 \mathrm{kDa}$ and $11 \mathrm{kDa}$ and $\beta 2$ microglobulin. Haverson et al. [91] described several monoclonal antibodies that appeared to recognise SLA class I antigens (1D10, 4B7/8, UCP1E9 and UCP1F9).

\subsection{Major histocompatibility complex class II}

SLA class II antigens, the second major group of histocompatibility antigens, are dimers of $\alpha(33-35 \mathrm{kDa})$ and $\beta(28-30 \mathrm{kDa})$ type I transmembrane proteins. The two chains are non-covalently associated.

The SLA class II region has been fully sequenced [51, 151, 198]. The SLA class II genes demonstrate high strong sequence homology with their human leukocyte antigen (HLA) counterparts. The overall arrangement of genes in the class II region is very similar to the HLA class II region, except that the length of the region is much shorter, there are no DP genes and it is separated from the class III region by the centromere.
Two independent groups of class II MHC molecules are found in pigs: SLA-DR, a $28 / 35 \mathrm{kDa}$ heterodimer similar to the murine I-E complex and human HLA-DR, and SLA$\mathrm{DQ}$, a $27 / 34 \mathrm{kDa}$ heterodimer corresponding to human HLA-DQ.

The class II loci comprise the SLA-D region and, consistent with human nomenclature, are designated as SLA DRA, SLA-DRB1, SLADQA ( $\alpha$-chain) and SLA-DQB1 ( $\beta$-chain). In the SLA-DRA locus, only two polymorphic sites were found in the $\alpha 1$ domain. The limited polymorphism in this region is of interest because the DRA locus in most species does not show any polymorphism in the peptide-binding portion of the protein, the $\alpha 1$ domain. In contrast, the SLA-DRB1 alleles show a highly polymorphic locus with 82 published alleles. The SLA-DQA corresponds to a moderate polymorphic locus with 20 representing alleles belonging to at least 4 groups. The SLA-DQB1 is a highly polymorphic locus with 44 published DNA sequences that represent alleles belonging to at least 9 groups [199].

SLA class II is expressed on dendritic cells, B cells, monocytes and macrophages and certain $\mathrm{T}$ cell subsets, whether resting or activated [49, 80, 197]. Expression may be induced or downregulated following the activation of epithelial and endothelial cells. Whilst the $\mathrm{CD}^{-}{ }^{-} \mathrm{CD} 8^{-} \mathrm{TcR}-\gamma \delta$ and the $\mathrm{CD} 4^{+} \mathrm{CD} 8^{-}$TcR- $\alpha \beta$ T cells lack MHC II, the $\mathrm{CD}^{-}{ }^{-} \mathrm{CD} 8^{+}$and $\mathrm{CD} 4^{+} \mathrm{CD}^{+} \alpha \beta$ T cell subsets (the latter of which is unique to swine) do express MHC II. As opposed to human T cells, expression of porcine MHC II is not transient and restricted to lymphoblasts but is immanent in small, resting $\mathrm{T}$ lymphocytes of the two $\mathrm{CD}^{+}$subsets $[170,172,176]$.

Mab MSA3 recognises a monomorphic determinant on the $28 / 30 \mathrm{kDa}$ SLA-DRw heterodimer [91], whereas $\mathrm{mAb} 2 \mathrm{~F} 4$ and FQ1D7 recognise $33 \mathrm{kDa}$ antigens that probably correspond to the $\alpha$ chain. An overview of the various $\mathrm{mAb}$ reacting with SLA class II antigens has been provided by Lunney and Pescovitz [121] and these antigens have also been the subject of another review [117, 119]. 


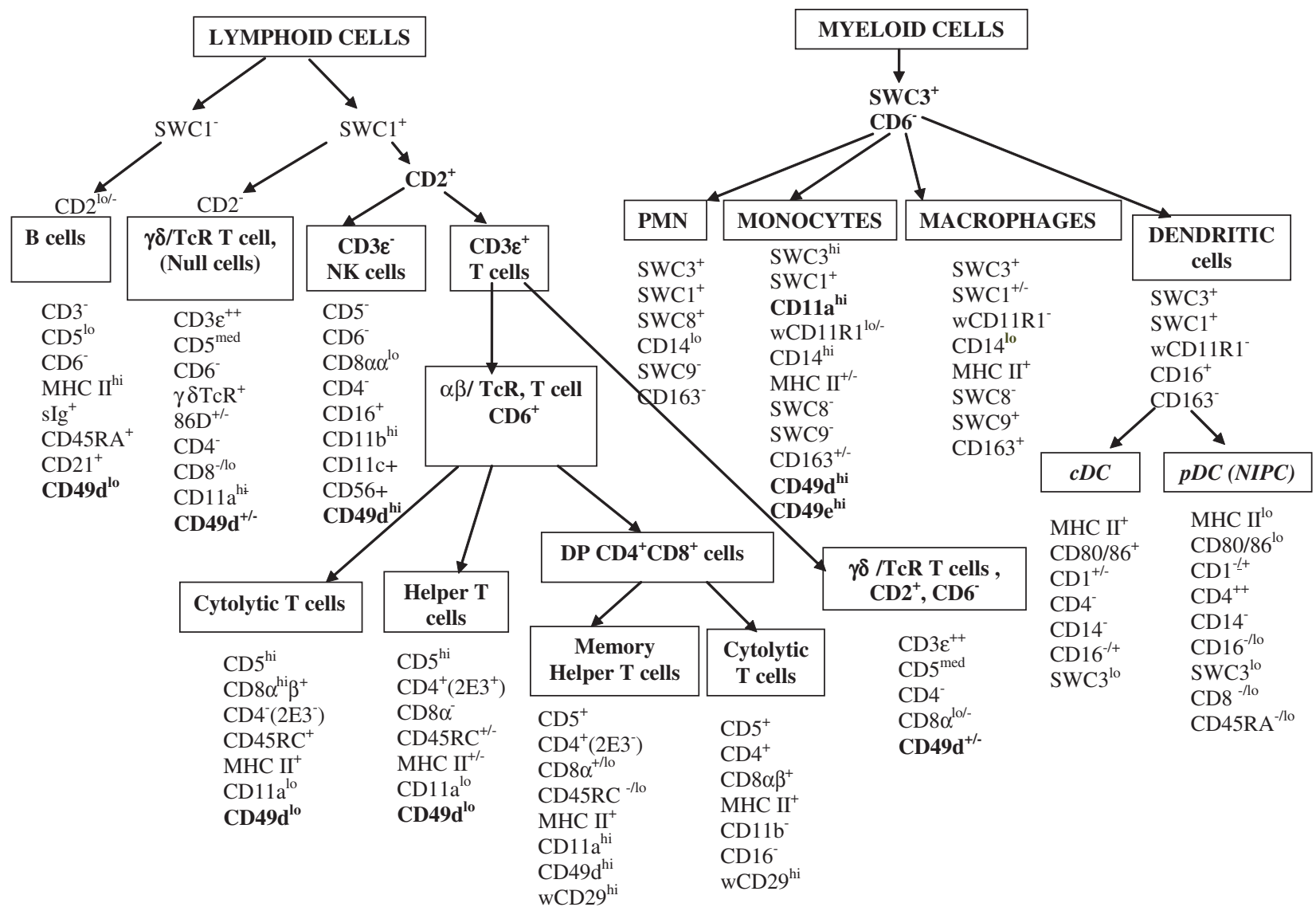

Figure 1. Phenotype of blood swine leukocytes, macrophages and dendritic cells as ascertained by discriminatory CD. Discriminatory CD are indicated as bold letters. (+) CD/SWC expressed; (-) CD/SWC not expressed; (+/-) variable expression; (hi) high density expression; (lo) low density expression. Note that: (i) most $\gamma \delta$-T cells are CD2- (and correspond to the Null cells according to the old definition) but some are CD2 ${ }^{+} \gamma \delta$-T cells; (ii) $\alpha \beta$-T cell, $\mathrm{CD} 4^{-} \mathrm{CD} 8^{\text {lo }}$ cell subset is not represented per se but among the $\mathrm{CD} 2^{+} \gamma \delta$-T cells; (iii) among DP (double positive) $\mathrm{CD} 4^{+} \mathrm{CD} 8^{+}$, cytolytic $\mathrm{T}$ cell [64]. 


\section{CONCLUSION}

Even with the limited resources available in porcine immunology, the various $\mathrm{mAb}$ identifying porcine $\mathrm{CD}$ on cells of the immune system listed in Table A dress the differences in binding distribution with respect to other species including humans and mice, and demonstrate the impact of new SWC marker on cell lineage and on function characterisations (Fig. 1). The various swine $\mathrm{CD}$ workshops have facilitated the development of collaborative interactions between immunologists, enabling the designation of new $\mathrm{mAb}$ as well as cross-reacting mAb to particular CD and SWC. This effort continues to improve porcine biomedical research, in particular a better knowledge of the porcine immune system. Furthermore, during the recent HLDA8 many more cross-reactive $\mathrm{mAb}$ have been identified as being directed against a wide range of $C D$ antigens of different species including CD1b, CD9, CD14, CD18, CD41, CD44, CD47, CD59, CD68, CD80, CD86, CD91, CD95, CD163, CD172a, CD247 [158, 171]. On the contrary, certain commercially available human polyclonal antisera may also represent useful tools [195]. This will improve our understanding of porcine immunology.

Acknowledgements. We thank Arthur Summerfield for valuable criticisms.

\section{REFERENCES}

[1] Aasted B., Viuff B., Reactivity of monoclonal antibodies to human CD antigens with cells from mink, Vet. Immunol. Immunopathol. (2007) 119:27-37.

[2] Ackermann M.R., DeBey B.M., Stabel T.J., Gold J.H., Register K.B., Meehan J.T., Distribution of antiCD68 (EBM11) immunoreactivity in formalin-fixed, paraffin-embedded bovine tissues, Vet. Pathol. (1994) 31:340-348.

[3] Alvarez B., Domenech N., Alonso F., Sanchez C., Gomez del Moral M., Ezquerra A., et al., Molecular and functional characterization of porcine LFA-1 using monoclonal antibodies to CD11a and CD18, Xenotransplantation (2000) 7:258-266.

[4] Alvarez B., Gomez N., Jose G.J., Yerle M., Revilla C., Chamorro S., et al., Molecular cloning characterization and expression of porcine immunoreceptor SIRPalpha, Dev. Comp. Immunol. (2007) 31:307-318

[5] Alvarez B., Sanchez C., Bullido R., Marina A., Lunney J., Alonso F., et al., A porcine cell surface receptor identified by monoclonal antibodies to SWC3 is a member of the signal regulatory protein family and associates with protein-tyrosine phosphatase SHP-1, Tissue Antigens (2000) 55:342-351.

[6] Appleyard G.D., Furesz S.E., Wilkie B.N., Blood lymphocyte subsets in pigs vaccinated and challenged with Actinobacillus pleuropneumoniae, Vet. Immunol. Immunopathol. (2002) 86:221-228.

[7] Appleyard G.D., Wilkie B.N., Characterization of porcine CD5 and $\mathrm{CD}^{+} \mathrm{B}$ cells, Clin. Exp. Immunol. (1998) 111:225-230.

[8] Armengol E., Wiesmuller K.H., Wienhold D., Buttner M., Pfaff E., Jung G., et al., Identification of T-cell epitopes in the structural and non-structural proteins of classical swine fever virus, J. Gen. Virol. (2002) 83:551-560.

[9] Arriens M.A., Summerfield A., McCullough K.C., Differential adhesion molecule expression on porcine mononuclear cell populations, Scand. J. Immunol. (1998) 47:487-495.

[10] Aversa G.G., Bishop G.A., Suranyi M.G., Hall B.M., RPA-2.10: an anti-CD2 monoclonal antibody that inhibits alloimmune responses and monitors $\mathrm{T}$ cell activation, Transplant. Proc. (1987) 19:277-278.

[11] Bailey M., Stevens K., Bland P.W., Stokes C.R., A monoclonal antibody recognising an epitope associated with pig interleukin-2 receptors, J. Immunol. Methods (1992) 153:85-91.

[12] Basta S., Knoetig S.M., Spagnuolo-Weaver M., Allan G., McCullough K.C., Modulation of monocytic cell activity and virus susceptibility during differentiation into macrophages, J. Immunol. (1999) 162:3961-3969.

[13] Batten P., Yacoub M.H., Rose M.L., Effect of human cytokines (IFN-gamma, TNF-alpha, IL-1 beta, IL-4) on porcine endothelial cells: induction of MHC and adhesion molecules and functional significance of these changes, Immunology (1996) 87:127-133.

[14] Bautista E.M., Gregg D., Golde W.T., Characterization and functional analysis of skin-derived dendritic cells from swine without a requirement for in vitro propagation, Vet. Immunol. Immunopathol. (2002) 88:131-148.

[15] Berg E.L., Goldstein L.A., Jutila M.A., Nakache M., Picker L.J., Streeter P.R., et al., Homing receptors and vascular addressins: cell adhesion molecules that direct lymphocyte traffic 23, Immunol. Rev. (1989) 108:5-18. 
[16] Bergamin F., Vincent I.E., Summerfield A., McCullough K.C., Essential role of antigen-presenting cell-derived BAFF for antibody responses, Eur. J. Immunol. (2007) 37:3122-3130.

[17] Berndt A., Heller M., Methner U., Kosmehl H., Muller G., Monoclonal antibodies against porcine macrophages, Vet. Immunol. Immunopathol. (2000) 74:163-177.

[18] Bie P.C., Nygard A.B., Fredholm M., Aasted B., Salomonsen J., Various domains of the B-cell regulatory molecule CD72 has diverged at different rates in mammals: cloning, transcription and mapping of porcine CD72, Dev. Comp. Immunol. (2007) 31:530-538.

[19] Bimczok D., Rau H., Wundrack N., Naumann M., Rothkötter H.J., McCullough K., et al., Cholera toxin promotes the generation of semi-mature porcine monocyte-derived dendritic cells that are unable to stimulate T cells, Vet. Res. (2007) 38:597-612.

[20] Bimczok D., Rothkötter H.J., Lymphocyte migration studies, Vet. Res. (2006) 37:325-338.

[21] Bimczok D., Sowa E.N., Faber-Zuschratter H., Pabst R., Rothkotter H.J., Site-specific expression of CD11b and SIRPalpha (CD172a) on dendritic cells: implications for their migration patterns in the gut immune system, Eur. J. Immunol. (2005) 35: 1418-1427.

[22] Binns R.M., Bone marrow and lymphoid cell injection of the pig foetus resulting in transplantation tolerance or immunity, and immunoglobulin production, Nature (1967) 214:179-180.

[23] Binns R.M., The Null/gamma delta TCR + T cell family in the pig, Vet. Immunol. Immunopathol. (1994) 43:69-77.

[24] Binns R.M., Bischof R., Carr M.M., Davis W.C., Licence S.T., Misfeldt M., et al., Report on the behaviour of monoclonal antibodies in the First International Pig CD Workshop identifying the Null cell families, Vet. Immunol. Immunopathol. (1994) 43:279-287.

[25] Binns R.M., Duncan I.A., Powis S.J., Hutchings A., Butcher G.W., Subsets of null and gamma delta T-cell receptor+ T lymphocytes in the blood of young pigs identified by specific monoclonal antibodies, Immunology (1992) 77:219-227.

[26] Binns R.M., Licence S.T., Whyte A., Wilby M., Rothkotter H.J., Bacon M., Genetically determined CD45 variant of value in leucocyte tracing in vivo in the pig, Immunology (1995) 86:25-33.

[27] Binns R.M., Whyte A., Licence S.T., Harrison A.A., Tsang Y.T., Haskard D.O., et al., The role of E-selectin in lymphocyte and polymorphonuclear cell recruitment into cutaneous delayed hypersensitivity reactions in sensitized pigs, J. Immunol. (1996) 157:4094-4099.

[28] Blecha F., Kielian T., McVey D.S., Lunney J.K., Walker K., Stokes C.R., et al., Workshop studies on monoclonal antibodies reactive against porcine myeloid cells, Vet. Immunol. Immunopathol. (1994) 43:269-272.

[29] Boersma W.J., Zwart R.J., Sinkora J., Rehakova Z., Haverson K., Bianchi A.T., Summary of workshop findings for porcine B-cell markers, Vet. Immunol. Immunopathol. (2001) 80:63-78.

[30] Bourges D., Chevaleyre C., Wang C., Berri M., Zhang X., Nicaise L., et al., Differential expression of adhesion molecules and chemokines between nasal and small intestinal mucosae: implications for $\mathrm{T}$ and sIgA+ B-lymphocyte recruitment, Immunology (2007) 122:551-561.

[31] Bourges D., Wang C.H., Chevaleyre C., Salmon $\mathrm{H}$., $\mathrm{T}$ and $\operatorname{IgA} \mathrm{B}$ lymphocytes of the pharyngeal and palatine tonsils: differential expression of adhesion molecules and chemokines, Scand. J. Immunol. (2004) 60:338-350.

[32] Bozić F., Lacković G., Stokes C.R., Valpotić I., Recruitment of intestinal CD45RA+ and CD45RC+ cells induced by a candidate oral vaccine against porcine post-weaning colibacillosis, Vet. Immunol. Immunopathol. (2002) 86:137-146.

[33] Brodersen R., Bijlsma F., Gori K., Jensen K.T., Chen W., Dominguez J., et al., Analysis of the immunological cross reactivities of 213 well characterized monoclonal antibodies with specificities against various leucocyte surface antigens of human and 11 animal species, Vet. Immunol. Immunopathol. (1998) 64:1-13.

[34] Brossay A., Hube F., Moreau T., Bardos P., Watier H., Porcine CD58: cDNA cloning and molecular dissection of the porcine CD58-human CD2 interface, Biochem. Biophys. Res. Commun. (2003) 309: 992-998.

[35] Bullido R., Alonso F., Gomez del Moral M., Ezquerra A., Alvarez B., Ortuno, et al., Monoclonal antibody $2 \mathrm{~F} 4 / 11$ recognizes the alpha chain of a porcine beta 2 integrin involved in adhesion and complement mediated phagocytosis, J. Immunol. Methods (1996) 195:125-134.

[36] Bullido R., Domenech N., Alvarez B., Alonso F., Babin M., Ezquerra A., et al., Characterization of five monoclonal antibodies specific for swine class II major histocompatibility antigens and crossreactivity studies with leukocytes of domestic animals, Dev. Comp. Immunol. (1997) 21:311-322.

[37] Bullido R., Domenech N., Gomez del Moral M., Alonso F., Ezquerra A., et al., Monoclonal antibodies 2F6/8 and 2A10/8 recognize a porcine antigen (SWC7)

Page 18 of 28 (page number not for citation purpose) 
expressed on B cells and activated T cells, J. Immunol. Methods (1999) 222:1-11.

[38] Bullido R., Gomez del Moral M., Alonso F., Ezquerra A., Zapata A., Sanchez C., et al., Monoclonal antibodies specific for porcine monocytes/macrophages: macrophage heterogeneity in the pig evidenced by the expression of surface antigens, Tissue Antigens (1997) 49:403-413.

[39] Bullido R., Gomez del Moral M., Domenech N., Alonso F., Ezquerra A., et al., Monoclonal antibodies to a high molecular weight isoform of porcine CD45: biochemical and tissue distribution analyses, Vet. Immunol. Immunopathol. (1997) 56:151-162.

[40] Bullido R., Perez de la Lastra J., Almazan F., Ezquerra A., Llanes D., Alonso F., et al., Induction of aggregation in porcine lymphoid cells by antibodies to CD46, Vet. Immunol. Immunopathol. (2000) 73:73-81.

[41] Butler J.E., Sinkora M., Wertz N., Holtmeier W., Lemke C.D., Development of the neonatal B and $\mathrm{T}$ cell repertoire in swine: implications for comparative and veterinary immunology, Vet. Res. (2006) $37: 417-441$.

[42] Butler J.E., Sun J., Wertz N., Sinkora M., Antibody repertoire development in swine, Dev. Comp. Immunol. (2006) 30:199-221.

[43] Calvert J.G., Slade D.E., Shields S.L., Jolie R., Mannan R.M., Ankenbauer R.G., et al., CD163 expression confers susceptibility to porcine reproductive and respiratory syndrome viruses, J. Virol. (2007) 81:7371-7379.

[44] Carr M.M., Howard C.J., Sopp P., Manser J.M., Parsons K.R., Expression on porcine gamma delta lymphocytes of a phylogenetically conserved surface antigen previously restricted in expression to ruminant gamma delta $\mathrm{T}$ lymphocytes, Immunology (1994) 81:36-40.

[45] Carr M.M., Lunney J.K., Arn S., Aasted B., Binns R.M., Davis W.C., et al., Summary of first round cluster analysis: complete antibody panel 386, Vet. Immunol. Immunopathol. (1994) 43:211-217.

[46] Carrasco C.P., Rigden R.C., Schaffner R., Gerber H., Neuhaus V., Inumaru S., et al., Porcine dendritic cells generated in vitro: morphological, phenotypic and functional properties, Immunology (2001) 104:175-184.

[47] Carrillo A., Chamorro S., Rodriguez-Gago M., Alvarez B., Molina M.J., Rodriguez-Barbosa J.I., et al., Isolation and characterization of immortalized porcine aortic endothelial cell lines, Vet. Immunol. Immunopathol. (2002) 89:91-98.

[48] Chamorro S., Revilla C., Alvarez B., Alonso F., Ezquerra A., Dominguez J., Phenotypic and functional heterogeneity of porcine blood monocytes and its relation with maturation, Immunology (2005) 114:63-71.

[49] Chamorro S., Revilla C., Gomez N., Alvarez B., Alonso F., Ezquerra A., et al., In vitro differentiation of porcine blood CD163- and CD163+ monocytes into functional dendritic cells, Immunobiology (2004) 209:57-65.

[50] Chardon P., Renard C., Gaillard C.R., Vaiman M., The porcine major histocompatibility complex and related paralogous regions: a review, Genet. Sel. Evol. (2000) 32:109-128.

[51] Chardon P., Renard C., Vaiman M., The major histocompatibility complex in swine, Immunol. Rev. (1999) 167:179-192.

[52] Charerntantanakul W., Roth J.A., Biology of porcine $\mathrm{T}$ lymphocytes, Anim. Health Res. Rev. (2006) 7:81-96.

[53] Chen L., Zwart R., Yang P., Kijlstra A., Macrophages and MHC class II positive dendritiform cells in the iris and choroid of the pig, Curr. Eye Res. (2003) 26:291-296.

[54] Choi I., Cho B., Kim S.D., Park D., Kim J.Y., Park C.G., et al., Molecular cloning, expression and functional characterization of miniature swine CD86, Mol. Immunol. (2006) 43:480-486.

[55] Chun T., Wang K., Zuckermann F.A., Gaskins H.R., Molecular cloning and characterization of a novel CD1 gene from the pig, J. Immunol. (1999) 162:6562-6571.

[56] Dato M.E., Kim Y.B., Characterization and utilization of a monoclonal antibody inhibiting porcine natural killer cell activity for isolation of natural killer and killer cells, J. Immunol. (1990) 144:4452-4462.

[57] Dato M.E., Wierda W.G., Kim Y.B., A triggering structure recognized by G7 monoclonal antibody on porcine lymphocytes and granulocytes, Cell. Immunol. (1992) 140:468-477.

[58] Davis T.A., Craighead N., Williams A.J., Scadron A., June C.H., Lee K.P., Primary porcine endothelial cells express membrane-bound B7-2 (CD86) and a soluble factor that co-stimulate cyclosporin A-resistant and CD28-dependent human T cell proliferation, Int. Immunol. (1996) 8:1099-1111.

[59] Davis W.C., Brown W.C., Hamilton M.J., Wyatt C.R., Orden J.A., Khalid A.M., et al., Analysis of monoclonal antibodies specific for the gamma delta TcR, Vet. Immunol. Immunopathol. (1996) 52:275-283.

[60] Davis W.C., Haverson K., Saalmuller A., Yang H., Lunney J.K., Hamilton M.J., et al., Analysis of monoclonal antibodies reacting with molecules expressed on gammadelta T-cells, Vet. Immunol. Immunopathol. (2001) 80:53-62. 
[61] Davis W.C., Zuckermann F.A., Hamilton M.J., Barbosa J.I., Saalmuller A., Binns R.M., et al., Analysis of monoclonal antibodies that recognize gamma delta T/null cells, Vet. Immunol. Immunopathol. (1998) 60:305-316.

[62] Denham S., Shimizu M., Bianchi A.T., Zwart R.J., Carr M.M., Parkhouse R.M., Monoclonal antibodies recognising differentiation antigens on porcine $\mathrm{B}$ cells, Vet. Immunol. Immunopathol. (1994) 43:259-267.

[63] Denham S., Zwart R.J., Whittall J.T., Pampusch M., Corteyn A.H., Bianchi A.T., et al., Monoclonal antibodies putatively identifying porcine B cells, Vet. Immunol. Immunopathol. (1998) 60:317-328.

[64] Denyer M.S., Wileman T.E., Stirling C.M., Zuber B., Takamatsu H.H., Perforin expression can define CD8 positive lymphocyte subsets in pigs allowing phenotypic and functional analysis of natural killer, cytotoxic $\mathrm{T}$, natural killer $\mathrm{T}$ and $\mathrm{MHC}$ un-restricted cytotoxic T-cells, Vet. Immunol. Immunopathol. (2006) 110:279-292.

[65] Diaz G., Canas B., Vazquez J., Nombela C., Arroyo J., Characterization of natural peptide ligands from HLA-DP2: new insights into HLA-DP peptidebinding motifs, Immunogenetics (2005) 56:754-759.

[66] Domenech N., Rodriguez-Carreno M.P., Filgueira P., Alvarez B., Chamorro S., Dominguez J., Identification of porcine macrophages with monoclonal antibodies in formalin-fixed, paraffin-embedded tissues, Vet. Immunol. Immunopathol. (2003) 94:77-81.

[67] Dominguez J., Alvarez B., Alonso F., Thacker E., Haverson K., McCullough K., et al., Workshop studies on monoclonal antibodies in the myeloid panel with CD11 specificity, Vet. Immunol. Immunopathol. (2001) 80:111-119.

[68] Dominguez J., Ezquerra A., Alonso F., Bullido R., McCullough K., Summerfield A., et al., Workshop studies with monoclonal antibodies identifying a novel porcine differentiation antigen, SWC9, Vet. Immunol. Immunopathol. (1998) 60:343-349.

[69] Dominguez J., Ezquerra A., Alonso F., McCullough K., Summerfield A., Bianchi A., et al., Porcine myelomonocytic markers: summary of the Second International Swine CD Workshop, Vet. Immunol. Immunopathol. (1998) 60:329-341.

[70] Donovan J.A., Koretzky G.A., CD45 and the immune response, J. Am. Soc. Nephrol. (1993) 4:976-985.

[71] Dorling A., Delikouras A., Nohadani M., Polak J., Lechler R.I., In vitro accommodation of porcine endothelial cells by low dose human anti-pig antibody: reduced binding of human lymphocytes by accommodated cells associated with increased nitric oxide production, Xenotransplantation (1998) 5:84-92.
[72] Ehrlich R., Lifshitz R., Pescovitz M.D., Rudikoff S., Singer D.S., Tissue-specific expression and structure of a divergent member of a class I MHC gene family, J. Immunol. (1987) 139:593-602.

[73] Evans P.C., Taylor E.R., Kilshaw P.J., Signaling through CD31 protects endothelial cells from apoptosis, Transplantation (2001) 71:457-460.

[74] Faas S.J., Giannoni M.A., Mickle A.P., Kiesecker C.L., Reed D.J., Wu D.Y., et al., Primary structure and functional characterization of a soluble, alternatively spliced form of B7-1, J. Immunol. (2000) 164:6340-6348.

[75] Faldyna M., Samankova P., Leva L., Cerny J., Oujezdska J., Rehakova Z., et al., Cross-reactive anti-human monoclonal antibodies as a tool for B-cell identification in dogs and pigs, Vet. Immunol. Immunopathol. (2007) 119:56-62.

[76] Feng W.H., Tompkins M.B., Xu J.S., Brown T.T., Laster S.M., Zhang H.X., et al., Thymocyte and peripheral blood T lymphocyte subpopulation changes in piglets following in utero infection with porcine reproductive and respiratory syndrome virus, Virology (2002) 302:363-372.

[77] Gao F.S., Fang Q.M., Li Y.G., Li X.S., Hao H.F., Xia C., Reconstruction of a swine SLA-I protein complex and determination of binding nonameric peptides derived from the foot-and-mouth disease virus, Vet. Immunol. Immunopathol. (2006) 113:328-338.

[78] Gerner W., Denyer M.S., Takamatsu H.H., Wileman T.E., Wiesmuller K.H., Pfaff E., et al., Identification of novel foot-and-mouth disease virus specific T-cell epitopes in c/c and d/d haplotype miniature swine, Virus Res. (2006) 121:223-228.

[79] Godwin J.W., d'Apice A.J., Cowan P.J., Characterization of pig intercellular adhesion molecule-2 and its interaction with human LFA-1, Am. J. Transplant. (2004) 4:515-525.

[80] Gonzalez J.M., Mebus C.A., Pan R., Revilla Y., Alonso J.M., Lunney J.K., Swine leukocyte antigen and macrophage marker expression on both African swine fever virus-infected and non-infected primary porcine macrophage cultures, Vet. Immunol. Immunopathol. (1992) 32:243-259.

[81] Gutierrez M., Forster F.I., McConnell S.A., Cassidy J.P., Pollock J.M., Bryson D.G., The detection of CD2+, CD4+, CD8+, and WC1+ T lymphocytes, $B$ cells and macrophages in fixed and paraffin embedded bovine tissue using a range of antigen recovery and signal amplification techniques, Vet. Immunol. Immunopathol. (1999) 71:321-334.

[82] Halloran P.J., Sweeney S.E., Strohmeier C.M., Kim Y.B., Molecular cloning and identification of the porcine cytolytic trigger molecule G7 as a Fc gamma 
RIII alpha (CD16) homologue, J. Immunol. (1994) 153:2631-2641.

[83] Hammerberg C., Schurig G.G., Characterization of monoclonal antibodies directed against swine leukocytes, Vet. Immunol. Immunopathol. (1986) 11:107-121.

[84] Harrison A.A., Stocker C.J., Chapman P.T., Tsang Y.T., Huehns T.Y., Gundel R.H., et al., Expression of vascular cell adhesion molecule-1 by vascular endothelial cells in immune and nonimmune inflammatory reactions in the skin, J. Immunol. (1997) 159:4546-4554.

[85] Haverson K., Bailey M., Higgins V.R., Bland P.W., Stokes C.R., Characterization of monoclonal antibodies specific for monocytes, macrophages and granulocytes from porcine peripheral blood and mucosal tissues, J. Immunol. Methods (1994) 170:233-245.

[86] Haverson K., Bailey M., Stokes C.R., Simon A., LeFlufy L., Banfield G., et al., Monoclonal antibodies raised to human cells-specificity for pig leukocytes, Vet. Immunol. Immunopathol. (2001) 80:175-186.

[87] Haverson K., Riffault S., Antigen presenting cells in mucosal sites of veterinary species, Vet. Res. (2006) 37:339-358.

[88] Haverson K., Saalmuller A., Alvarez B., Alonso F., Bailey M., Bianchi A.T., et al., Overview of the third international workshop on swine leukocyte differentiation antigens, Vet. Immunol. Immunopathol. (2001) 80:5-23.

[89] Haverson K., Saalmuller A., Chen Z., Huang C.A., Simon A., Seebach J., et al., Summary of the first round analyses of the third international workshop on swine leukocyte differentiation antigens, Vet. Immunol. Immunopathol. (2001) 80:25-34.

[90] Haverson K., Singha S., Stokes C.R., Bailey M., Professional and non-professional antigen-presenting cells in the porcine small intestine, Immunology (2000) 101:492-500.

[91] Haverson K., Zuckermann F., Saalmuller A., Lipp J., Aasted B., Stokes C.R., Summary of workshop findings for porcine adhesion molecule subgroup, Vet Immunol. Immunopathol. (1998) 60:351-365.

[92] Hirt W., Saalmuller A., Reddehase M.J., Distinct gamma/delta $\mathrm{T}$ cell receptors define two subsets of circulatingX porcine CD2-CD4-CD8- T lymphocytes, Eur. J. Immunol. (1990) 20:265-269.

[93] Ivanoska D., Sun D.C., Lunney J.K., Production of monoclonal antibodies reactive with polymorphic and monomorphic determinants of SLA class I gene products, Immunogenetics (1991) 33:220-223.

[94] Jimenez-Marin A., Garrido J.J., de AndresCara D.F., Morera L., Barbancho M.J., Llanes D.,
Molecular cloning and characterization of the pig homologue to human $\mathrm{CD} 29$, the integrin beta1 subunit, Transplantation (2000) 70:649-655.

[95] Jimenez-Marin A., Moreno A., de la Mulas J.M., Millan Y., Morera L., Barbancho M., et al., Localization of porcine CD29 transcripts and protein in pig cells and tissues by RT-PCR and immunohistochemistry, Vet. Immunol. Immunopathol. (2005) 104:281-288.

[96] Jones M., Cordell J.L., Beyers A.D., Tse A.G., Mason D.Y., Detection of $\mathrm{T}$ and $\mathrm{B}$ cells in many animal species using cross-reactive antipeptide antibodies 32, J. Immunol. (1993) 150: 5429-5435.

[97] Jonjic S., Koszinowski U.H., Monoclonal antibodies reactive with swine lymphocytes. I. Antibodies to membrane structures that define the cytolytic $\mathrm{T}$ lymphocyte subset in the swine, J. Immunol. (1984) 133:647-652.

[98] Kaeffer B., Bottreau E., Marcon D., Olivier M., Lantier I., Salmon H., Histocompatible miniature pig (d/d haplotype): generation of hybridomas secreting A or M monoclonal antibody, Hybridoma (1991) 10:731-744

[99] Kaeffer B., Bottreau E., Phan T.L., Olivier M., Salmon H., Histocompatible miniature, boar model: selection of transformed cell lines of B and T lineages producing retrovirus, Int. J. Cancer (1990) 46:481-488.

[100] Kamata T., Puzon W., Takada Y., Identification of putative ligand-binding sites of the integrin alpha 4 beta 1 (VLA-4, CD49d/CD29), Biochem. J. (1995) 305:945-951.

[101] Kanan J.H., Nayeem N., Binns R.M., Chain B.M., Mechanisms for variability in a member of the scavenger-receptor cysteine-rich superfamily, Immunogenetics (1997) 46:276-282.

[102] Kansas G.S., Spertini O., Stoolman L.M., Tedder T.F., Molecular mapping of functional domains of the leukocyte receptor for endothelium, LAM-1, J. Cell Biol. (1991) 114:351-358.

[103] Kaser T., Gerner W., Hammer S.E., Patzl M., Saalmuller A., Phenotypic and functional characterisation of porcine $\mathrm{CD} 4(+) \mathrm{CD} 25$ (high) regulatory $\mathrm{T}$ cells, Vet. Immunol. Immunopathol. (2008) 122:153-158.

[104] Kasper M., Bierhaus A., Whyte A., Binns R.M., Schuh D., Muller M., Expression of CD44 isoforms during bleomycin-or radiation-induced pulmonary fibrosis in rats and mini-pigs, Histochem. Cell Biol. (1996) 105:221-230.

[105] Keelan E.T., Harrison A.A., Chapman P.T., Binns R.M., Peters A.M., Haskard D.O., Imaging vascular endothelial activation: an approach using 
radiolabeled monoclonal antibodies against the endothelial cell adhesion molecule E-selectin, J. Nucl. Med. (1994) 35:276-281.

[106] Kenmochi T., Mullen Y., Miyamoto M., Stein E., Swine as an allotransplantation model, Vet. Immunol. Immunopathol. (1994) 43:177-183.

[107] Kielian T., McVey D.S., Davis W.C., Kim Y.B., Blecha F., Competitive binding analysis of monoclonal antibodies reactive with porcine alveolar macrophages using anti-CD14 and anti-CD18, Vet. Immunol. Immunopathol. (1994) 43:273-278.

[108] Kim Y.B., Developmental immunity in the piglet, Birth Defects Orig. Artic. Ser. (1975) 11: 549-557.

[109] Kim Y.B., Zhang J., Davis W.C., Lunney J.K., CD11/CD18 panel report for swine CD workshop, Vet. Immunol. Immunopathol. (1994) 43:289-291.

[110] Kimman T.G., Bianchi A.T., Wensvoort G., de Bruin T.G., Meliefste C., Cellular immune response to hog cholera virus (HCV): $\mathrm{T}$ cells of immune pigs proliferate in vitro upon stimulation with live $\mathrm{HCV}$, but the E1 envelope glycoprotein is not a major T-cell antigen, J. Virol. (1993) 67:2922-2927.

[111] Kirkham P.A., Takamatsu H., Yang H., Parkhouse R.M., Porcine CD3 epsilon: its characterization, expression and involvement in activation of porcine $\mathrm{T}$ lymphocytes, Immunology (1996) 87:616-623.

[112] Kirkiles-Smith N.C., Tereb D.A., Kim R.W., McNiff J.M., Schechner J.S., Lorber M.I., et al., Human TNF can induce nonspecific inflammatory and human immune-mediated microvascular injury of pig skin xenografts in immunodeficient mouse hosts 13 , J. Immunol. (2000) 164:6601-6609.

[113] Kuhns M.S., Davis M.M., Garcia K.C., Deconstructing the form and function of the TCR/CD3 complex, Immunity (2006) 24:133-139.

[114] Kumagai-Braesch M., Schacter B., Yan Z., Michaelson J., Arn S., Smith M., et al., Identification of swine and primate cellular adhesion molecules (CAM) using mouse anti-human monoclonal antibodies, Xenotransplantation (1995) 2:88-97.

[115] Llanes D., Arce C., de la Lastra J.P., de A.D., Barbancho M., Morera L., et al., Swine platelet antigens: section report, Vet. Immunol. Immunopathol. (2001) 80:131-142.

[116] Lopez F.L., Domenech N., Alvarez B., Ezquerra A., Dominguez J., Castro J.M., et al., Analysis of cellular immune response in pigs recovered from porcine respiratory and reproductive syndrome infection, Virus Res. (1999) 64:33-42.

[117] Lunney J., Pescovitz M.D., Differentiation antigens in swine lymphoid tissues, in: Miyasaka M.,
Trnka Z. (Eds.), Differentiation antigens in lymphohemopoietic tissues, Marcel Dekker, New-York and Basel, 1998, pp. 421-454.

[118] Lunney J.K., Characterization of swine leukocyte differentiation antigens, Immunol. Today (1993) 14:147-148.

[119] Lunney J.K., Current status of the swine leukocyte antigen complex, Vet. Immunol. Immunopathol. (1994) 43:19-28.

[120] Lunney J.K., Fossum C., Alm G.V., Steinbach F., Wattrang E., Veterinary immunology: opportunities and challenges, Trends Immunol. (2002) 23:4-6.

[121] Lunney J.K., Pescovitz M.D., Phenotypic and functional characterization of pig lymphocyte populations, Vet. Immunol. Immunopathol. (1987) $17: 135-144$

[122] Lunney J.K., Walker K., Goldman T., Aasted B., Bianchi A., Binns R., et al., Overview of the First International Workshop to Define Swine Leukocyte Cluster of Differentiation (CD) Antigens, Vet. Immunol. Immunopathol. (1994) 43:193-206.

[123] Mackay C.R., Marston W.L., Dudler L., Spertini O., Tedder T.F., Hein W.R., Tissue-specific migration pathways by phenotypically distinct subpopulations of memory T cells, Eur. J. Immunol. (1992) 22: 887-895.

[124] Magyar A., Mihalik R., Characterisation of the swine swC1 antigen, Acta Vet. Hung. (1997) 45:17-31.

[125] Maher S.E., Karmann K., Min W., Hughes C.C., Pober J.S., Bothwell A.L., Porcine endothelial CD86 is a major costimulator of xenogeneic human $\mathrm{T}$ cells: cloning, sequencing, and functional expression in human endothelial cells, J. Immunol. (1996) 157:3838-3844.

[126] Makala L.H., Haverson K., Stokes C.R., Bailey M., Bland P.W., Isolation and characterisation of pig Peyer's patch dendritic cells, Vet. Immunol. Immunopathol. (1998) 61:67-81.

[127] Martins C.L., Lawman M.J., Scholl T., Mebus C.A., Lunney J.K., African swine fever virus specific porcine cytotoxic T cell activity, Arch. Virol. (1993) 129:211-225.

[128] McCullough K.C., Schaffner R., Natale V., Kim Y.B., Summerfield A., Phenotype of porcine monocytic cells: modulation of surface molecule expression upon monocyte differentiation into macrophages, Vet. Immunol. Immunopathol. (1997) 58:265-275.

[129] Mehrazar K., Kim Y.B., Total parenteral nutrition in germfree colostrum-deprived neonatal miniature piglets: a unique model to study the 
ontogeny of the immune system, J. Parenter. Enteral Nutr. (1988) 12:563-568.

[130] Merono A., Lucena C., Lopez A., Garrido J.J., Perez de L.L., Llanes D., Immunohistochemical analysis of beta3 integrin (CD61): expression in pig tissues and human tumors, Histol. Histopathol. (2002) 17:347-352.

[131] Mueller J.P., Evans M.J., Cofiell R., Rother R.P., Matis L.A., Elliott E.A., Porcine vascular cell adhesion molecule (VCAM) mediates endothelial cell adhesion to human T cells. Development of blocking antibodies specific for porcine VCAM, Transplantation (1995) 60:1299-1306.

[132] Murray A.G., Khodadoust M.M., Pober J.S. Bothwell A.L.M., Porcine Aortic Endothelial-Cells Activate Human T-Cells - Direct Presentation of Mhc Antigens and Costimulation by Ligands for Human Cd2 and Cd28, Immunity (1994) 1:57-63.

[133] Naessens J., Newson J., McHugh N., Howard C.J., Parsons K., Jones B., Characterization of a bovine leucocyte differentiation antigen of 145,000 MW restricted to B lymphocytes, Immunology (1990) 69:525-530.

[134] Outteridge P.M., Binns R.M., Licence S.T. Subpopulations of pig blood E-rosette-forming lymphocytes and thymus-dependent null cells: separation by nylon wool columns, rosette formation and macrophage-dependent mitogen and antigen responsiveness, Int. Arch. Allergy Appl. Immunol (1982) 67:18-24.

[135] Panja A., Barone A., Mayer L., Stimulation of lamina propria lymphocytes by intestinal epithelial cells: evidence for recognition of nonclassical restriction elements, J. Exp. Med. (1994) 179:943-950.

[136] Panos G., Moreno A., Jimenez-Marin A., Garrido J.J., Martin de la Mulas J., Ordas J., et al., Analysis of swine betal integrin (CD29) epitopes through monoclonal antibodies developed using two immunization strategies, Hybrid. Hybridomics (2004) 23 271-278.

[137] Pauly T., Elbers K., Konig M., Lengsfeld T., Saalmuller A., Thiel H.J., Classical swine fever virusspecific cytotoxic $\mathrm{T}$ lymphocytes and identification of a T cell epitope, J. Gen. Virol. (1995) 76:3039-3049.

[138] Pauly T., Weiland E., Hirt W., Dreyer-Bux C., Maurer S., Summerfield A., et al., Differentiation between MHC-restricted and non-MHC-restricted porcine cytolytic T lymphocytes, Immunology (1996) $88: 238-246$.

[139] Pescovitz M.D., Aasted B., Canals A., Dominguez J., Vizcaino J.S., Pospisil R., et al., Analysis of monoclonal antibodies reactive with the porcine CD2 antigen, Vet. Immunol. Immunopathol. (1994) 43:229-232.
[140] Pescovitz M.D., Aasted B., Canals A., Dominguez J., Vizcaino J.S., Pospisil R., et al., Analysis of monoclonal antibodies reactive with the porcine CD4 antigen, Vet. Immunol. Immunopathol. (1994) 43:233-236.

[141] Pescovitz M.D., Book B.K., Aasted B., Dominguez J., Bullido R., Trebichavsky I., et al., Analyses of monoclonal antibodies reacting with porcine CD5: results from the Second International Swine CD Workshop, Vet. Immunol. Immunopathol. (1998) 60:269-273.

[142] Pescovitz M.D., Book B.K., Aasted B., Dominguez J., Ezquerra A., Trebichavsky I., et al., Analyses of monoclonal antibodies reacting with porcine CD3: results from the Second International Swine CD Workshop, Vet. Immunol. Immunopathol. (1998) 60:261-268.

[143] Pescovitz M.D., Book B.K., Aasted B., Dominguez J., Ezquerra A., Trebichavsky I., et al., Summary of workshop findings for antibodies reacting with porcine T-cells and activation antigens: results from the Second International Swine CD Workshop, Vet. Immunol. Immunopathol. (1998) 60:251-260.

[144] Pescovitz M.D., Lunney J.K., Sachs D.H., Preparation and characterization of monoclonal antibodies reactive with porcine PBL, J. Immunol. (1984) 133:368-375.

[145] Pescovitz M.D., Lunney J.K., Sachs D.H., Murine anti-swine T4 and T8 monoclonal antibodies: distribution and effects on proliferative and cytotoxic T cells, J. Immunol. (1985) 134:37-44.

[146] Pescowitz D., Sakopoulos A.G., Gaddy J.A., Husmann R.J., Zuckermann F.A., Porcine peripheral blood CD4+/CD8+ dual expressing T-cells, Vet. Immunol. Immunopathol. (1994) 43:53-62.

[147] Pescowitz M.D., Hsu S.M., Katz S.I., Lunney J.K., Shimada S., Sachs D.H., Characterization of a porcine $\mathrm{CD} 1$-specific $\mathrm{mAb}$ that distinguishes CD4/CD8 double-positive thymic from peripheral T lymphocytes, Tissue Antigens (1990) 35:151-156.

[148] Petersen C.B., Nygard A.B., Viuff B., Fredholm M., Aasted B., Salomonsen J., Porcine ectonucleotide pyrophosphatase/phosphodiesterase 1 (NPP1/CD203a): cloning, transcription, expression, mapping, and identification of an NPP1/CD203a epitope for swine workshop cluster 9 (SWC9) monoclonal antibodies, Dev. Comp. Immunol. (2007) 31:618-631.

[149] Petruzzelli L., Maduzia L., Springer T.A., Activation of lymphocyte function-associated molecule-1 (CD11a/CD18) and Mac-1 (CD11b/CD18) mimicked by an antibody directed against CD18, J. Immunol. (1995) 155:854-866.

[150] Pintaric M., Gerner W., Saalmuller A., Synergistic effects of IL-2, IL-12 and IL-18 on cytolytic 
activity, perforin expression and IFN-gamma production of porcine natural killer cells, Vet. Immunol. Immunopathol. (2007) 121:68-82.

[151] Renard C., Hart E., Sehra H., Beasley H., Coggill P., Howe K., et al., The genomic sequence and analysis of the swine major histocompatibility complex, Genomics (2006) 88:96-110.

[152] Revilla C., Chamorro S., Alvarez B., Perez C., Ezquerra A., Alonso F., et al., Analysis of functional heterogeneity of porcine memory CD4+ T cells, Dev. Comp. Immunol. (2005) 29:479-488.

[153] Revilla C., Rodriguez-Carreno M.P., Alvarez B., Chamorro S., Alonso L.M., Ezquerra A., et al., 2E3, a new marker that selectively identifies porcine CD4+ naive T cells, Dev. Comp. Immunol. (2004) 28:239-250.

[154] Richard C., Charreau B., Vusio P., Soulillou J.P., Bouhours J.F., Characterization of two monoclonal antibodies against porcine VCAM-1, Hybridoma (1999) 18:159-165.

[155] Riffault S., Carrat C., van Reeth K., Pensaert M., Charley B., Interferon-alpha-producing cells are localized in gut-associated lymphoid tissues in transmissible gastroenteritis virus (TGEV) infected piglets, Vet. Res. (2001) 32:71-79.

[156] Rothkotter H.J., Ulbrich H., Pabst R., The postnatal development of gut lamina propria lymphocytes: number, proliferation, and $\mathrm{T}$ and $\mathrm{B}$ cell subsets in conventional and germ-free pigs, Pediatr. Res. (1991) 29:237-242.

[157] Saalmuller A., Characterization of swine leukocyte differentiation antigens, Immunol. Today (1996) 17:352-354.

[158] Saalmuller A., Aasted B., Summary of the animal homologue section of HLDA8, Vet. Immunol. Immunopathol. (2007) 119:2-13.

[159] Saalmuller A., Aasted B., Canals A., Dominguez J., Goldman T., Lunney J.K., et al., Analyses of monoclonal antibodies reactive with porcine CD6, Vet. Immunol. Immunopathol. (1994) 43:243-247.

[160] Saalmuller A., Aasted B., Canals A., Dominguez J., Goldman T., Lunney J.K., et al., Analyses of $\mathrm{mAb}$ reactive with porcine $\mathrm{CD} 8$, Vet. Immunol. Immunopathol. (1994) 43:249-254.

[161] Saalmuller A., Aasted B., Canals A., Dominguez J., Goldman T., Lunney J.K., et al., Analyses of monoclonal antibodies reactive with porcine CD5, Vet. Immunol. Immunopathol. (1994) 43:237-242.

[162] Saalmuller A., Aasted B., Canals A., Dominguez J., Goldman T., Lunney J.K., et al., Summary of workshop findings for porcine T-lymphocyte antigens, Vet. Immunol. Immunopathol. (1994) 43: 219-228.

Page 24 of 28 (page number not for citation purpose)
[163] Saalmuller A., Aasted B., Canals A., Dominguez J., Goldman T., Lunney J.K., et al., Analysis of mAb reactive with the porcine SWC1, Vet. Immunol. Immunopathol. (1994) 43:255-258.

[164] Saalmuller A., Bryant J., Characteristics of porcine T lymphocytes and T-cell lines, Vet. Immunol. Immunopathol. (1994) 43:45-52.

[165] Saalmuller A., Denham S., Haverson K., Davis B., Dominguez J., Pescovitz M.D., et al., The Second International Swine CD Workshop, Vet. Immunol. Immunopathol. (1996) 54:155-158.

[166] Saalmuller A., Hirt W., Maurer S., Weiland E., Discrimination between two subsets of porcine CD8+ cytolytic T lymphocytes by the expression of CD5 antigen, Immunology (1994) 81:578-583.

[167] Saalmuller A., Hirt W., Reddehase M.J., Phenotypic discrimination between thymic and extrathymic CD4-CD8- and CD4+CD8+ porcine T lymphocytes, Eur. J. Immunol. (1989) 19:2011-2016.

[168] Saalmuller A., Hirt W., Reddehase M.J., Porcine gamma/delta $\mathrm{T}$ lymphocyte subsets differing in their propensity to home to lymphoid tissue, Eur. J. Immunol. (1990) 20:2343-2346.

[169] Saalmuller A., Jonjic S., Buhring H.J., Reddehase M.J., Koszinowski U.H., Monoclonal antibodies reactive with swine lymphocytes. II. Detection of an antigen on resting $\mathrm{T}$ cells down-regulated after activation, J. Immunol. (1987) 138:1852-1857.

[170] Saalmuller A., Kuebart G., Hollemweguer E., Chen Z., Nielsen J., Zuckermann F., et al., Summary of workshop findings for porcine T-lymphocyte-specific monoclonal antibodies, Vet. Immunol. Immunopathol. (2001) 80:35-52.

[171] Saalmuller A., Lunney J.K., Daubenberger C., Davis W., Fischer U., Gobel T.W., et al., Summary of the animal homologue section of HLDA8, Cell. Immunol. (2005) 236:51-58.

[172] Saalmuller A., Maurer S., Major histocompatibility antigen class II expressing resting porcine T lymphocytes are potent antigen-presenting cells in mixed leukocyte culture, Immunobiology (1994) 190:23-34.

[173] Saalmuller A., Pauly T., Hohlich B.J., Pfaff E., Characterization of porcine $\mathrm{T}$ lymphocytes and their immune response against viral antigens, J. Biotechnol. (1999) 73:223-233.

[174] Saalmuller A., Pauly T., Lunney J.K., Boyd P., Aasted B., Sachs D.H., et al., Overview of the Second International Workshop to define swine cluster of differentiation (CD) antigens, Vet. Immunol. Immunopathol. (1998) 60:207-228.

[175] Saalmuller A., Reddehase M.J., Buhring H.J., Jonjic S., Koszinowski U.H., Simultaneous expression of CD4 and CD8 antigens by a substantial proportion 
of resting porcine T lymphocytes, Eur. J. Immunol. (1987) 17:1297-1301.

[176] Saalmuller A., Weiland F., Reddehase M.J., Resting porcine $\mathrm{T}$ lymphocytes expressing class II major histocompatibility antigen, Immunobiology (1991) 183:102-114.

[177] Saalmuller A., Werner T., Fachinger V., T-helper cells from naive to committed, Vet. Immunol. Immunopathol. (2002) 87:137-145.

[178] Sachs D.H., Immunologic tolerance to organ transplants, J. Gastrointest. Surg. (1999) 3:105-110.

[179] Saif L.J., Ward L.A., Yuan L., Rosen B.I., To T.L., The gnotobiotic piglet as a model for studies of disease pathogenesis and immunity to human rotaviruses, Arch. Virol. Suppl. (1996) 12:153-161.

[180] Salmon H., Surface markers of porcine lymphocytes and distribution in various lymphoid organs, Int. Arch. Allergy Appl. Immunol. (1979) 60:262-274.

[181] Salmon H., Swine thymic dendritic cell: an another means to induce the transplantation tolerance: Characterization, isolation and cell culture, in: Laplace J.P., Fevrier C., Barbeau A. (Eds.), Digestive Physiology in pigs, 1997, pp. 661-666.

[182] Salmon H., Mammary gland immunology and neonate protection in pigs. Homing of lymphocytes into the MG, Adv. Exp. Med. Biol. (2000) 480:279-86:279-286.

[183] Salmon H., Johnson I., Germana S., Haller G.W., Sachs D.H., Leguern C., Dendritic cells enriched from swine thymus co-express CD1, CD2 and major histocompatibility complex class II and actively stimulate alloreactive T lymphocytes, Scand. J. Immunol. (2000) 52:164-172.

[184] Salmon H., Vaiman M., Scheuer D., Immunologie du porc, in: Pastoret P.P., Govaerts A., Bazin H. (Eds.), Immunologie animale, Flammarion, Médecine-sciences, Paris, 1-1-1990, pp. 565-578.

[185] Sanchez C., Domenech N., Vazquez J., Alonso F., Ezquerra A., Dominguez J., The porcine 2A10 antigen is homologous to human CD163 and related to macrophage differentiation, J. Immunol. (1999) 162:5230-5237.

[186] Saurer L., McCullough K.C., Summerfield A., In vitro induction of mucosa-type dendritic cells by all-trans retinoic acid, J. Immunol. (2007) 179:3504-3514.

[187] Schneider M.K., Forte P., Seebach J.D., Adhesive interactions between human NK cells and porcine endothelial cells, Scand. J. Immunol. (2001) 54:70-75.

[188] Schnitzlein W.M., Zuckermann F.A., Determination of the specificity of CD45 and CD45R monoclonal antibodies through the use of transfected hamster cells producing individual porcine CD45 isoforms, Vet. Immunol. Immunopathol. (1998) 60:389-401.

[189] Schutt C., Schilling T., Stelter F., Furll B., Kruger C., Witt S., et al., Modalities of endotoxin binding to CD14, Prog. Clin. Biol. Res. (1995) 392:339-48:339-348.

[190] Shailubhai K., Streeter P.R., Smith C.E., Jacob G.S., Sulfation and sialylation requirements for a glycoform of CD34, a major endothelial ligand for L-selectin in porcine peripheral lymph nodes, Glycobiology (1997) 7:305-314.

[191] Simon A.R., Warrens A.N., Sykes M., Efficacy of adhesive interactions in pig-to-human xenotransplantation, Immunol. Today (1999) 20:323-330.

[192] Sinkora J., Rehakova Z., Haverson K., Sinkora M., et al., Monoclonal antibodies putatively recognising activation and differentiation antigens, Vet. Immunol. Immunopathol. (2001) 80:143-164.

[193] Sinkora J., Rehakova Z., Samankova L., Haverson K., Butler J.E., Zwart R., et al., Characterization of monoclonal antibodies recognizing immunoglobulin kappa and lambda chains in pigs by flow cytometry, Vet. Immunol. Immunopathol. (2001) 80:79-91.

[194] Sinkora J., Rehakova Z., Sinkora M., Cukrowska B., Tlaskalova-Hogenova H., Bianchi A.T., et al., Expression of $\mathrm{CD} 2$ on porcine B lymphocytes, Immunology (1998) 95:443-449.

[195] Sinkora M., Butler J.E., Holtmeier W., Sinkorova J., Lymphocyte development in fetal piglets: facts and surprises, Vet. Immunol. Immunopathol. (2005) 108:177-184.

[196] Sinkora M., Sinkora J., Rehakova Z., Splichal I., Yang H., Parkhouse R.M., et al., Prenatal ontogeny of lymphocyte subpopulations in pigs, Immunology (1998) 95:595-603.

[197] Sinkora M., Sinkorova J., Butler J.E., B cell development and VDJ rearrangement in the fetal pig, Vet. Immunol. Immunopathol. (2002) 87:341-346.

[198] Smith D.M., Lunney J.K., Ho C.S., Martens G.W., Ando A., Lee J.H., et al., Nomenclature for factors of the swine leukocyte antigen class II system, 2005, Tissue Antigens (2005) 66:623-639.

[199] Smith D.M., Lunney J.K., Martens G.W., Ando A., Lee J.H., Ho C.S., et al., Nomenclature for factors of the SLA class-I system, 2004, Tissue Antigens (2005) 65:136-149.

[200] Soderholm J., Ahlen G., Kaul A., Frelin L., Alheim M., Barnfield C., et al., Relation between viral fitness and immune escape within the hepatitis $C$ virus protease, Gut (2006) 55:266-274.

[201] Solano-Aguilar G.I., Vengroski K.G., Beshah E., Douglass L.W., Lunney J.K., Characterization of 
lymphocyte subsets from mucosal tissues in neonatal swine, Dev. Comp. Immunol. (2001) 25:245-263.

[202] Sonnenberg A., Linders C.J., Daams J.H., Kennel S.J., The alpha 6 beta 1 (VLA-6) and alpha 6 beta 4 protein complexes: tissue distribution and biochemical properties, J. Cell Sci. (1990) 96:207-217.

[203] Sopp P., Kwong L.S., Howard C.J., Identification of bovine CD14, Vet. Immunol. Immunopathol. (1996) 52:323-328.

[204] Sopp P., Redknap L., Howard C., Crossreactivity of human leucocyte differentiation antigen monoclonal antibodies on porcine cells, Vet. Immunol. Immunopathol. (1998) 60:403-408.

[205] Steeber D.A., Venturi G.M., Tedder T.F., A new twist to the leukocyte adhesion cascade: intimate cooperation is key, Trends Immunol. (2005) 26:9-12.

[206] Stocker C.J., Sugars K.L., Harari O.A., Landis R.C., Morley B.J., Haskard D.O., TNF-alpha, IL-4, and IFN-gamma regulate differential expression of Pand E-selectin expression by porcine aortic endothelial cells, J. Immunol. (2000) 164:3309-3315.

[207] Stocker C.J., Sugars K.L., Yarwood H., Delikouras A., Lechler R.I., Dorling A., et al., Cloning of porcine intercellular adhesion molecule-1 and characterization of its induction on endothelial cells by cytokines, Transplantation (2000) 70:579-586.

[208] Summerfield A., Guzylack-Piriou L., Schaub A., Carrasco C.P., Tache V., Charley B., et al., Porcine peripheral blood dendritic cells and natural interferonproducing cells, Immunology (2003) 110:440-449.

[209] Summerfield A., Haverson K., Thacker E., McCullough K.C., Differentiation of porcine myeloid bone marrow haematopoietic cell populations, Vet. Immunol. Immunopathol. (2001) 80:121-129.

[210] Summerfield A., McCullough K.C., Porcine bone marrow myeloid cells: phenotype and adhesion molecule expression, J. Leukoc. Biol. (1997) 62:176-185.

[211] Summerfield A., Saalmuller A., Interleukin-2 dependent selective activation of porcine gamma delta $\mathrm{T}$ lymphocytes by an extract from the leaves of Acanthospermum hispidum, Int. J. Immunopharmacol. (1998) 20:85-98

[212] Sun J., Sinkora J., Wertz N., Moravkova A., Butler J.E., Characterization of porcine CD19 and anti-CD19 monoclonal antibodies, Mol. Immunol. (2004) 41:929-938.

[213] Susa M., Konig M., Saalmuller A., Reddehase M.J., Thiel H.J., Pathogenesis of classical swine fever: B-lymphocyte deficiency caused by hog cholera virus,

J. Virol. (1992) 66:1171-1175.
[214] Sweeney S.E., Kim Y.B., Identification of a novel Fc gamma RIIIa alpha-associated molecule that contains significant homology to porcine cathelin, J. Immunol. (2004) 172:1203-1212.

[215] Tadaki D.K., Williams A., Lee K.P., Kirk A.D., Harlan D.M., Porcine CD80: cloning, characterization, and evidence for its role in direct human T-cell activation, Xenotransplantation (2003) 10: 252-258.

[216] Takamatsu H.H., Denyer M.S., Stirling C., Cox S., Aggarwal N., Dash P., et al., Porcine gammadelta $\mathrm{T}$ cells: possible roles on the innate and adaptive immune responses following virus infection, Vet. Immunol. Immunopathol. (2006) 112:49-61.

[217] Takamatsu H.H., Denyer M.S., Wileman T.E., A sub-population of circulating porcine gammadelta $\mathrm{T}$ cells can act as professional antigen presenting cells, Vet. Immunol. Immunopathol. (2002) 87:223-224.

[218] Tang W.R., Shioya N., Eguchi T., Ebata T., Matsui J., Takenouchi H., et al., Characterization of new monoclonal antibodies against porcine lymphocytes: molecular characterization of clone $7 \mathrm{G} 3$, an antibody reactive with the constant region of the T-cell receptor delta-chains, Vet. Immunol. Immunopathol. (2005) 103:113-127.

[219] Tanneau G.M., Hibrand-Saint O.L., Chevaleyre C.C., Salmon H.P., Differential recruitment of $\mathrm{T}$ - and $\operatorname{IgA}$ B-lymphocytes in the developing mammary gland in relation to homing receptors and vascular addressins, J. Histochem. Cytochem. (1999) 47:1581-1592.

[220] Thacker E., Summerfield A., McCullough K., Ezquerra A., Dominguez J., Alonso F., et al., Summary of workshop findings for porcine myelomonocytic markers, Vet. Immunol. Immunopathol. (2001) 80:93-109.

[221] Thome M., Hirt W., Pfaff E., Reddehase M.J., Saalmuller A., Porcine T-cell receptors: molecular and biochemical characterization, Vet. Immunol. Immunopathol. (1994) 43:3-18.

[222] Travnicek J., Mandel L., Trebichavsky I., Talafantova M., Immunological state of adult germfree miniature Minnesota pigs, Folia Microbiol. (Praha) (1989) 34:157-164.

[223] Tsang Y.T., Haskard D.O., Robinson M.K., Cloning and expression kinetics of porcine vascular cell adhesion molecule, Biochem. Biophys. Res. Commun. (1994) 201:805-812.

[224] Tsang Y.T., Stephens P.E., Licence S.T., Haskard D.O., Binns R.M., Robinson M.K., Porcine E-selectin: cloning and functional characterization, Immunology (1995) 85:140-145. 
[225] Van der Stede Y., Verdonck F., Verfaillie T., Goddeeris B.M., Cox E., Porcine-specific CpGoligodeoxynucleotide activates B-cells and increases the expression of MHC-II molecules on lymphocytes28, Vet. Immunol. Immunopathol. (2005) 105:115-124.

[226] Vaughan A.N., Malde P., Rogers N.J., Jackson I.M., Lechler R.I., Dorling A., Porcine CTLA4-Ig lacks a MYPPPY motif, binds inefficiently to human B7 and specifically suppresses human CD4+ T cell responses costimulated by pig but not human B7, J. Immunol. (2000) 165:3175-3181.

[227] Vega-Lopez M.A., Bailey M., Telemo E., Stokes C.R., Effect of early weaning on the development of immune cells in the pig small intestine 20, Vet. Immunol. Immunopathol. (1995) 44:319-327.

[228] Wada M., Amae S., Sasaki H., Ishii T., Sano N., Nio M., et al., The functional roles of porcine CD80 molecule and its ability to stimulate and regulate human anti-pig cellular response, Transplantation (2003) 75:1887-1894.

[229] Warnecke G., Avsar M., Morancho M., Peters C., Thissen S., Kruse B., et al., Preoperative low-dose irradiation promotes long-term allograft acceptance and induces regulatory $\mathrm{T}$ cells in a porcine model of pulmonary transplantation, Transplantation (2006) 82:93-101.

[230] Whyte A., Wooding P., Nayeem N., Watson S.R., Rosen S.D., Binns R.M., The L-selectin counterreceptor in porcine lymph nodes, Biochem. Soc. Trans. (1995) 23:159S

[231] Wienhold D., Berger N., Armengol E., Buttner M., Saalmuller A., Pfaff E., Cloning, sequencing and expression of porcine CD40 ligand in Escherichia coli and human and porcine cells, Cytokine (2002) 20:274-282.

[232] Wierda W.G., Johnson B.D., Dato M.E., Kim Y.B., Induction of porcine granulocyte-mediated tumor cytotoxicity by two distinct monoclonal antibodies against lytic trigger molecules (PNK-E/G7), J. Immunol. (1993) 151:7117-7127.

[233] Yang H., Binns R.M., CD44 is not directly involved in the binding of lymphocytes to cultured high endothelial cells from peripheral lymph nodes, Immunology (1993) 79:418-424.

[234] Yang H., Binns R.M., Expression and regulation of the porcine CD44 molecule, Cell. Immunol. (1993) 149:117-129.

[235] Yang H., Binns R.M., Isolation and characterization of the soluble and membrane-bound porcine CD44 molecules, Immunology (1993) 78:547-554.
[236] Yang H., Hutchings A., Binns R.M., Preparation and reactivities of anti-porcine CD44 monoclonal antibodies, Scand. J. Immunol. (1993) 37:490-498.

[237] Yang H., Lan C., Xiao Y., Chen Y.H., Antibody to CD14 like CXCR4-specific antibody 12G5 could inhibit CXCR4-dependent chemotaxis and HIV Env-mediated cell fusion, Immunol. Lett. (2003) 88:27-30.

[238] Yang H., Oura C.A., Kirkham P.A., Parkhouse R.M., Preparation of monoclonal anti-porcine CD3 antibodies and preliminary characterization of porcine T lymphocytes, Immunology (1996) 88:577-585.

[239] Yang H., Parkhouse R.M., Phenotypic classification of porcine lymphocyte subpopulations in blood and lymphoid tissues, Immunology (1996) 89:76-83.

[240] Yang H., Parkhouse R.M., Differential expression of CD8 epitopes amongst porcine CD8-positive functional lymphocyte subsets, Immunology (1997) 92:45-52.

[241] Yang H., Parkhouse R.M., Differential activation requirements associated with stimulation of $\mathrm{T}$ cells via different epitopes of CD3, Immunology (1998) 93:26-32.

[242] Yang H., Parkhouse R.M., Characterization of the porcine gammadelta T-cell receptor structure and cellular distribution by monoclonal antibody PPT27, Immunology (2000) 99:504-509.

[243] Yang H., Parkhouse R.M., Wileman T., Monoclonal antibodies that identify the CD3 molecules expressed specifically at the surface of porcine gammadelta-T cells, Immunology (2005) 115: 189-196.

[244] Yim D., Sotiriadis J., Kim K.S., Shin S.C., Jie H.B., Rothschild M.F., et al., Molecular cloning, expression pattern and chromosomal mapping of pig CD69, Immunogenetics (2002) 54:276-281.

[245] Ziegler-Heitbrock H.W., Appl B., Kafferlein E., Loffler T., Jahn-Henninger H., Gutensohn W., et al., The antibody MY4 recognizes CD14 on porcine monocytes and macrophages, Scand. J. Immunol. (1994) 40:509-514.

[246] Zuckermann F.A., Extrathymic CD4/CD8 double positive T cells, Vet. Immunol. Immunopathol. (1999) 72:55-66.

[247] Zuckermann F.A., Binns R.M., Husmann R., Yang H., Carr M.M., Kim Y.B., et al., Analyses of monoclonal antibodies reactive with porcine CD44 and CD45, Vet. Immunol. Immunopathol. (1994) 43:293-305. 
[248] Zuckermann F.A., Gaskins H.R., Distribution of porcine $\mathrm{CD} 4 / \mathrm{CD} 8$ double-positive $\mathrm{T}$ lymphocytes in mucosa-associated lymphoid tissues, Immunology (1996) 87:493-499.

[249] Zuckermann F.A., Husmann R.J., Functional and phenotypic analysis of porcine peripheral blood CD4/CD8 double-positive $\mathrm{T}$ cells, Immunology (1996) 87:500-512.

[250] Zuckermann F.A., Peavey C., Schnitzlein W.M., Schabacker D., Husmann R.J., Yang H., et al., Definition of the specificity of monoclonal antibodies against porcine CD45 and CD45R: report from the CD45/CD45R and CD44 subgroup of the Second International Swine CD Workshop, Vet. Immunol. Immunopathol. (1998) 60:367-387.
[251] Zuckermann F.A., Pescovitz M.D., Aasted B., Dominguez J., Trebichavsky I., Novikov B., et al., Report on the analyses of mAb reactive with porcine CD8 for the second international swine CD workshop, Vet. Immunol. Immunopathol. (1998) 60:291-303.

[252] Zuckermann F.A., Schabacker D., Binns R.M., Biochemical analysis of molecules reactive with monoclonal antibodies specific for porcine CD45, Vet. Immunol. Immunopathol. (1994) 43:307-313.

[253] Zuckermann F.A., Schnitzlein W.M., Thacker E., Sinkora J., Haverson K., Characterization of monoclonal antibodies assigned to the CD45 subgroup of the Third International Swine CD Workshop, Vet. Immunol. Immunopathol. (2001) 80:165-174. 